\title{
Circular Economy Business Models for the Tanzanian Coffee Sector: A Teaching Case Study
}

\author{
Francesco Paolo Lagrasta *(D), Pierpaolo Pontrandolfo $(\mathbb{D}$ and Barbara Scozzi \\ Department of Mechanics, Mathematics \& Management, Politecnico di Bari, Via Orabona 4, 70126 Bari, BA, Italy; \\ pierpaolo.pontrandolfo@poliba.it (P.P.); barbara.scozzi@poliba.it (B.S.) \\ * Correspondence: francescopaolo.lagrasta@poliba.it
}

check for updates

Citation: Lagrasta, F.P.; Pontrandolfo, P.; Scozzi, B. Circular Economy

Business Models for the Tanzanian Coffee Sector: A Teaching Case Study. Sustainability 2021, 13, 13931. https:// doi.org/10.3390/su132413931

Academic Editor: Luis Jesús Belmonte-Ureña

Received: 26 October 2021

Accepted: 10 December 2021

Published: 16 December 2021

Publisher's Note: MDPI stays neutral with regard to jurisdictional claims in published maps and institutional affiliations.

Copyright: (c) 2021 by the authors. Licensee MDPI, Basel, Switzerland. This article is an open access article distributed under the terms and conditions of the Creative Commons Attribution (CC BY) license (https:// creativecommons.org/licenses/by/ $4.0 /)$.

\begin{abstract}
One of the major issues the agri-food supply chains is the considerable production of by-products, which are mostly discarded as wastes and dangerously landfilled. This problem is particularly acute in the coffee supply chain: coffee cultivation generates by-products and in quantities which are potentially dangerous for the environment. A circular economy business model aimed at the recovery of these by-products may represent an interesting solution in terms of environmental, social, and economic sustainability. The goal of this paper was to provide teachers and educators with case material on circular business models that can be used for problem-based learning and case-based learning activities. The proposed case was built to address a real-world problematic situation related to the coffee supply chain. From a theoretical point of view, this study contributes to the literature on circular economy business models by providing a case study developed in the context of a developing country. Furthermore, the research entails practical implications since it shows managers and startuppers how to map a circular business model in all its components under the guidance of a conceptual framework.
\end{abstract}

Keywords: circular economy; circular business model; case study; problem-based learning; casebased learning; education for sustainable development; coffee by-products; business model canvas; sustainable business model innovation framework; developing countries

\section{Introduction}

The production of food for an ever-growing population is an epochal issue that takes on the contours of a societal grand challenge [1]. With reference to the agri-food sector, the Food and Agriculture Organization of the United Nations estimates that $50 \%$ of habitable land is used for the production of food [2] and that food production together with its distribution is responsible for $26 \%$ of worldwide $\mathrm{CO}_{2}$ emissions [3]. The agri-food sector is not only responsible for such significant environmental impacts: agri-food production patterns are frequently implicated in the generation and preservation of unfavorable socioeconomic conditions that affect producers often located in developing countries [4-6]. Furthermore, a large part of the resources used for the production and distribution of food is vainly squandered: the Food and Agriculture Organization estimates that one-third of globally produced food is wasted or lost every year [7]. However, food value chains suffer from inefficiencies that are not solely linked to the waste of finished products. The great majority of activities related to food production is responsible for the generation of considerable amounts of by-products, which are often considered mere wastes [8,9]. This is especially the case in the agri-food sector, where value chains are failing to exploit all those by-products produced in the various stages of cultivation and processing of agricultural products' [10].

Several actors, including supranational institutions, governments, businesses, professionals, and academics, are converging to recognize the unsustainability of the current take-make-use-dispose flow of materials and energy, and point out the possible solution of 
the circular economy (CE) [11]. The CE paradigm proposes a flow model that is alternative to the take-make-use-dispose model and aims to preserve energy, components and materials at their maximum value and utility in all life cycle phases to minimize the use of virgin resources, and therefore, preserve natural capital. The positive effects of the adoption of $\mathrm{CE}$ are not expected to be only limited to the environmental dimension, but also to the social and economic ones $[12,13]$. The adoption of CE business models could drive employment rate and gross domestic product (GDP) gains [14,15], a decrease in social inequalities [16], the adoption of fair trade practices, and food security [17]. Korhonen et al. referred to the three-fold value (environmental, economic, and social) of the CE as a potential solution to the challenge of global sustainable development, labeling it as a "win-win-win solution" [11].

The agri-food sector is one of the sectors that could benefit the most, in terms of environmental, social, and economical sustainability, from the introduction of CE flow models $[7,10,18,19]$ (p. 37). The European Commission indicated that food is one of the value chain targets of the incentive policies for the $\mathrm{CE}$ transition, together with electronics, batteries and vehicles, packaging, plastics, textiles, and building materials [20] (p. 12). This shift is not isolated, however: in recent years, several policies have aimed to encourage the establishment of CE business models in the agri-food sector [21].

Although environmental and social issues are becoming increasingly salient and despite the growing political interest in encouraging CE solutions, there is a general scarcity of case studies aimed at illustrating how companies and practitioners can practically design and implement CE business models [22]. The numerous calls for papers made in recent years aimed at stimulating research on the subject demonstrate the growing interest for case studies on CE business models (e.g., [23,24]). Most of the existing studies are focused on the theoretical understanding of the paradigm as well as on the development of taxonomies and classifications [25] and fail to provide practical examples of the development and implementation of CE business models. The lack of case studies in the context of developing countries is particularly severe, resulting in a research gap recognized by many authors (e.g., [26-28]). This assumes paradoxical contours if we consider that such countries are often referred to as the potentially main beneficiaries of the CE paradigm shift $[26,29]$.

Furthermore, although the alignment between strategies (e.g., business models) and operations (e.g., business processes) [30] plays a fundamental role to ensure the transition to the CE paradigm [31-33], there is a lack of studies aimed at deepening the relationships between business strategy and business processes within companies adopting CE [34] and consequently, there is also a lack of material for educational purposes [35,36]. The development of adequate knowledge and domain skills by professionals is a fundamental prerequisite for the transition to the CE paradigm [14]. The use of case studies is a teaching practice widely recognized for its effectiveness [35,36]. In particular, problem-based learning (PBL) and case-based learning (CBL) have proven to be particularly effective in teaching approaches to business and management [37] and are considered among the best teaching practices for the transfer of CE knowledge and competences [38].

The goal of this paper was to provide teachers and educators with case material on circular business models that can be used for problem-based learning and case-based learning activities. The proposed case is built to address a real-world problematic situation related to the coffee supply chain. Such a model was developed to solve the problem introduced by leading small Tanzanian coffee producers to the upcycling of some cultivation and processing by-products. The coffee supply chain is an effective scenario for integrating CE business models within the agri-food sector [39], given its transnational nature, its large size, the high quantities of by-products generated, and the centrality it plays in many developing countries.

The case study was built in order to support PBL and CBL teaching approaches, providing educators with suitable material for the design of engaging and challenging teaching activities. 
While addressing the educational goal, this study contributes to extending the existing literature on CE business models by providing an example from the agri-food sector in the context of developing countries. This study also provides an in-depth analytical description of a CE business model related to the agri-food sector. Such a description can be used by managers, startuppers, and practitioners as an example of the CE business model framework-driven analysis.

This paper is structured as follows. In Section 2, an overview of the main concepts, classifications and frameworks useful to develop a CE business model is provided. In Section 3, the methodologies used to describe the problematic situation and analyze the case study are introduced. In Sections 4 and 5, we present the problematic situation and the CE business model to address it. The model is mapped by using the sustainable circular business model innovation framework. Section 6 explains how to use the case for CBL and PBL teaching activities. After discussing the implications of the research in Section 7, the limits of the research as well as some future research avenues are reported in the Conclusions (Section 8).

\section{Literature Review}

\subsection{Circular Economy}

Since 2016, the related literature has counted multiple attempts to systematically analyze the different definitions of CE that have been coined over time [40-48].

Kirchherr et al. [41] identified over 110 definitions of CE derived from the analysis of peer-reviewed scientific articles as well as of policy papers and reports. Their study identified the CE definition provided by the Ellen McArthur Foundation [13] as the most employed one: "[CE is] an industrial system that is restorative or regenerative by intention and design. It replaces the "end-of-life" concept with restoration, shifts towards the use of renewable energy, eliminates the use of toxic chemicals, which impair reuse, and aims for the elimination of waste through the superior design of materials, products, systems, and, within this, business models". Although this is the most adopted definition of CE, both Geissdoerfer et al. [40] and Kirchherr et al. [41], among others, proposed alternatives. According to Kirchherr et al., " ... a circular economy describes an economic system that is based on business models, which replaces the "end-of-life" concept with reducing, alternatively reusing, recycling and recovering materials in production/distribution and consumption processes, thus operating at the micro level (products, companies, consumers), meso level (eco-industrial parks) and macro level (city, region, nation and beyond), with the aim to accomplish sustainable development, which implies creating environmental quality, economic prosperity and social equity, to the benefit of current and future generations". Geissdoerfer et al. $[40,42]$ proposed a different definition, highlighting how the one articulated by Kirchherr places the greater emphasis on the concept of end-of-life than on the holistic one of life cycle, neglecting how the CE paradigm is conceptually based on the cycling, extending, intensifying, and dematerializing of materials and energy loops. According to Geissdoerfer et al., CE is " ... an economic system in which resource input and waste, emission, and energy leakages are minimised by cycling, extending, intensifying, and dematerialising material and energy loops. This can be achieved through digitalisation, servitisation, sharing solutions, long-lasting product design, maintenance, repair, reuse, remanufacturing, refurbishing, and recycling". This definition does not attribute to CE a constitutive telos, which was instead identified by Kirchherr [41] as sustainable development. On the other hand, the relationship between CE and sustainable development in its three-fold dimension (economic, environmental, and social) is not universally recognized: while some authors identified environmental and economic sustainability as constitutive aims of CE [43], aspects relating to social sustainability seem not to be included in the paradigm. In particular, some CE solutions, such as those placed at the intersection between $\mathrm{CE}$ and sharing economy, have even been shown to increase social inequalities [49].

In this work, we embraced the definition provided by Geissdoerfer et al. [40] though recognizing sustainable development as the frame for the CE paradigm. This choice is 
coherent with the national and international political agenda related to CE [20,50]. In addition, some studies have argued the CE to have a role in the path towards social sustainability $[17,51]$, especially from an occupational perspective.

\subsection{Business Models and Circular Business Models}

Every company operating in our economic system explicitly or implicitly adopts a business model that describes how it creates and captures value for and from its customers. Business models are therefore of considerable importance in market economies, de facto describing the strategies adopted by economic agents to make businesses and profits [22,52,53].

As reported by Zott et al. [54], in the existing literature, researchers have referred to business models by using several phrases: "statement, description, representation, architecture, conceptual tool, model, template, framework, pattern, set". This range of concepts suffices to highlight the heterogeneity of the definitions associated with business models. The quantity and diversity of definitions provided in the literature did not help clarify what exactly a business model is. Jensen [55], while navigating through several different notions, wonders whether it is necessary to converge on a single definition. In general, however, net of the literal definition and those used in research and functional to subsequent operationalizations, a business model can be identified as "a focal firm's core logic for creating, delivering and capturing value within a stakeholder network". Geissdoerfer et al. [40] identified two strands in the literature relating to the function of business models: according to the first, a business model is a tool for systemic analysis, planning, and communication; for the second, a business model is a strategic asset for competitive advantage and firm performance.

The centrality that business models play within the CE paradigm is widely documented and recognized [40]. In particular, the literature recognizes that the transition to CE business models operated by economic agents plays a pivotal role in the systemic adoption of the CE paradigm [56].

The concept of the CE business model is relatively recent compared to that of the CE [40]. The first authors which used the expression "circular economy business model" were Schwager and Moser in 2006 [57], when exploring the domain of CE solutions within the chemical industry. Since then, many authors and institutions have used the expression; however, defining its meaning in a precise and univocal way has been of lesser concern [40]. Geissdoerfer et al. [40] collect 14 different definitions of CE business model, highlighting their similarities and differences. Almost all of the definitions focus on the concepts of creating, delivering, and capturing value, associating these with the principles of CE and translating them into CE business models.

Oghazi and Mostaghel [58] defined the CE business model as " ... the rationale of how an organisation creates, delivers, and captures value with slowing, closing, or narrowing flows of the resource loops", directly referring to the energy and materials loops and citing the three main CE loops strategies (slowing, closing, and narrowing). Other authors have highlighted how CE business models are to be considered intrinsically devoted to sustainability in its three dimensions, thus coming to consider CE business models as a subset of sustainable business models [59-61]. For instance, Lahti et al. [60] stated that " ... we propose a circular business model definition to explain how an established firm uses innovations to create, deliver, and capture value through the implementation of CE principles, whereby the business rational are realigned between the network of actors/stakeholders to meet environmental, social, and economic benefits". This definition of the CE business model is in line with the definition of CE which we adopted in this work, which embeds sustainability as a constitutive telos of the CE paradigm.

Starting from the definitions of CE and from real cases, many scholars have engaged in empirically and/or theoretically deriving the taxonomies and classifications of CE business models and strategies. 
In [62], Bocken et al. identified two families of circular strategies, namely slowing the loops and closing the loops strategies. Slowing the loops strategies aimed to encourage a more extensive and/or intensive use of products and services in order to increase the efficiency of the resources employed. This category includes circular strategies based on: (i) sharing the use of a good or service among several users (access and performance model); (ii) avoiding discarding products or services with a residual value still associated (extending product value); (iii) providing users with products and/or services of increased durability (classic long-term model); (iv) limiting the consumption of the end user through marketing, sales, and assistance strategies, relying on a non-consumerist approach (encouraging sufficiency). On the other hand, closing the loops strategies aim to recover resources from the final market (extending resource value) or from the industrial fabric (industrial symbiosis). The strategies listed so far provide a relatively comprehensive overview of $\mathrm{CE}$ business model strategies and there have been numerous different attempts to categorize and taxonomize them. Geissoderfer et al. [40] identified four categories of CE business model strategies based on the four different CE solutions listed in the above given CE definition (Section 2.1): cycling strategies; extending strategies; intensifying strategies; and dematerializing strategies. In [63], Lüdeke-Freund et al. obtained the Morphological Toolbox, a tool capable of graphically rendering the design options of a CE business model from the analysis of 26 models. Lüdeke-Freund et al. identified four constituent components of a business model (value proposition, value delivery, value creation, value capture) and indicated for each component a series of options useful for defining as well as designing a CE business model.

\subsection{Business Model Canvas and Circular Business Model Canvas}

Most of the mapping tools for business models, such as the Morphological Toolbox [63], are aimed at the visualization of business models through the production of graphic artefacts. It is widely recognized that the graphic representation of BMs reduces their perceived complexity [54,64], promotes their communication [65], and enhances their understanding [66]. The representation of business models is therefore useful at different levels: at the academic research level, to prepare the raw data for subsequent analysis and enhance collaboration through standardized communication; at a practical level, to understand complex business models, have an easily readable artefact, and stimulate business model innovation; at the teaching level, to facilitate the understanding and transmission of complex information and to prompt creative and sustainable thinking. Among all the graphical business model mapping tools, the Business Model Canvas stands out [66] as it is in fact the most widespread BM mapping and visualization tool in the academic and entrepreneurial environment [67].

The development of the Business Model Canvas has its roots in the doctoral thesis conducted at the University of Lausanne by Alexander Osterwalder under the guidance of Professor Yves Pigneur [68]. Osterwalder conducted an in-depth literature review, and identified nine building blocks which eventually constituted the Business Model Canvas framework. The nine blocks aim to constitute an ontological framework able to render explicit the components (ontological categories) of a business model and the relationships among them [69]. The nine building blocks are the following:

- Customer segments that the organization serves or aims to serve with its products or services;

- Value proposition that the organization offers in order to solve customers' problems, and/or satisfy customers' implicit or explicit needs;

- Channels that the organization uses to deliver products and/or services to the customers;

- Customer relationships built and maintained with the customers by the organizations;

- Revenue streams obtained from the value proposition successfully delivered to the customers;

- Cost structure that the organization incurs in order to create and deliver value to the customer; 
- Key activities that the organization performs in order to create, deliver, and capture value;

- Key resources that the organization needs to perform its activities;

- Key partnerships that the organization has to entertain with some stakeholders which are crucial for the business model execution.

Multiple attempts can be traced within the literature to adapt the Business Model Canvas to CE business model representation [48]. Dewulf [70] added two additional blocks to the nine Business Model Canvas blocks; respectively, societal costs and societal benefits. Such blocks identify two ontological categories aimed at recording the externalities (positive and negative), in environmental and social terms, of the represented business model. The authors motivated the choice by underlining how the Osterwalder's [69] Business Model Canvas exclusively contemplated costs and revenues (i.e., the economic dimension). By integrating the triple bottom line [71], a framework was obtained that was able to better represent the overall business model sustainability. Taking into account the work of Dewulf [70], Antikainen and Valkokari [72] designed the sustainable circular business model innovation framework aimed at the CE business models' design and configuration, which takes into account both the aspects relating to the (positive and negative) sustainability impacts and the CE business model ecosystem. To this end, Antinaken and Valkokari added four additional blocks to Osterwalder's Business Model Canvas: trends and drivers, stakeholder involvement, sustainability requirements, and sustainability benefits. The latter two constitute ontological categories similar to those identified in [70] with societal costs and societal benefits. The "trends and drivers" block aims to identify those context factors (e.g., legislative, cultural) necessary for the implementation of the CE business model, while the "stakeholder involvement" category identifies those actions, in terms of stakeholder participation, which are critical for the correct implementation of the $\mathrm{CE}$ business model.

Daou et al. [73] discussed the Ecocanvas (a version of the Business Model Canvas developed by Nicola Cerantola and available under the Creative \& Commons AttributionShareAlike 4.0 license on www.aprendre.economiacircular.online (accessed on 11 September 2021) as a means of representing CE business models that takes into account the threats (environmental, social and economic) that could undermine the linear business model in the future. Lewandowski [48] developed a circular business model canvas that included two new building blocks: "take back system" and "adoption factors". The "take back system" block contains the management resources as well as the channels and the customer relationships that the organization has to develop and maintain in order to perform reverse logistics activities. The "adoption factors" block is an ontological category containing internal and external resources and conditions affecting the adaptation of the examined business model transition to CE.

\section{Materials and Methods}

The aim of this study was to build a teaching case study about CE solutions that are potentially adoptable by Tanzanian coffee producers. Tanzanian coffee producers record negative performance in terms of environmental, social, and economic sustainability. The adoption of innovative CE business models could represent an effective solution, preventing the mismanagement of coffee by-products and providing new revenue streams. The teaching case study consisted of two parts. The first part dealt with the narration of the real-world problematic situation referring to Tanzanian coffee producers. In the second part, a CE business model to address the problem was proposed and discussed. In the present section, after a brief introduction of the case study research and teaching case study, we describe the material and methods used to develop the teaching case study. In particular, Section 3.1 presents the methodologies used to design the teaching case study and the teaching approaches supported (i.e., PBL and CBL). Data sources as well as the approach adopted to process those data are reported in Sections 3.2 and 3.3. 


\subsection{Teaching Case Study and Learning Approaches}

A case study is an empirical inquiry aimed at investigating current or past phenomena, which constitutes the unit of analysis of case research [74]. Case research allows the questions "why", "what", and "how" to be answered through the understanding of complexity of the observed phenomenon [75]. Case studies can be useful for different purposes, ranging from exploration (i.e., to discover new areas for research and theory development) to theory extension/refinement (i.e., to improve theory in light of the obtained results) [76].

A teaching case study is slightly different from a research case study. Basically, the aim of a teaching case study is to ease knowledge transfer through the narration of an "interesting story" [77]. Initially adopted in law courses, teaching case studies play a pivotal role in business and management teaching practice.

Conducting a teaching case study-based lesson often involves submitting a problematic situation to the students-one filled with contradictions, dilemmas, and controversies [77,78]. Exposing classes to problematic situations is also the basis of PBL and is a long tradition in the medical field as well as a preferred tools for the transmission of diagnostic investigation skills [79]. PBL has been used in the business and management area [80] with positive results in terms of knowledge acquisition and knowledge application when compared with a traditional education approach [37]. When adopting a PBL approach, the problematic situation of interest is submitted to the class using a narrative artifact (a problem description) in line with the needs and the resources of the participants. A problem presentation can also be asked of students that previously had access to problem information. Following the narration, the class performed a series of activities aimed at estimating the understanding of the problem, generating a potential solution, and discussing its limits. When the teaching activity focuses on the guided inquiry of an existing solution, the teaching approach deviates from PBL to CBL. In CBL, students are guided through the stages of understanding the problem and finding a solution, and the facilitator plays a central role in guiding students towards solutions that are in line with the intended educational objectives. The cased-based approach also requires students to have accumulated knowledge related to the problem topic before the teaching activity starts. Table 1 summarizes the main features of PBL and CBL during the different stages of an educational activity.

Table 1. Problem-based learning and case-based learning: main features (adapted from [81]).

\begin{tabular}{ccc}
\hline & Problem-Based Learning & Case-Based Learning \\
\hline $\begin{array}{c}\text { Students' pre-activities } \\
\text { preparation }\end{array}$ & None & Previous knowledge needed \\
\hline $\begin{array}{c}\text { Students' approach during the } \\
\text { problem solving phase }\end{array}$ & $\begin{array}{c}\text { Teamwork, no interaction } \\
\text { with the faculty }\end{array}$ & $\begin{array}{c}\text { Teamwork and class } \\
\text { discussion, interaction with } \\
\text { the faculty (questions } \\
\text { and answers) }\end{array}$ \\
\hline $\begin{array}{c}\text { Faculty approach during the } \\
\text { problem solving phase }\end{array}$ & $\begin{array}{c}\text { Moderator role, no correction } \\
\text { of students' mistakes }\end{array}$ & $\begin{array}{c}\text { Provision of corrective } \\
\text { information, discussion of } \\
\text { alternatives, redirection } \\
\text { of discussion }\end{array}$ \\
\hline $\begin{array}{c}\text { Students' use of external } \\
\text { resources during the session }\end{array}$ & $\begin{array}{c}\text { Highly recommended and } \\
\text { encouraged }\end{array}$ & \begin{tabular}{c} 
None \\
\hline
\end{tabular}
\end{tabular}

CBL and PBL, together with business games and other interactive activities, are indicated as the preferred teaching approaches to transfer CE knowledge and skills $[38,82,83]$. In order to adopt these teaching approaches, it is necessary to have structurally designed teaching material to support them. To this end, in this research, a narrative of the real-world problematic situation which relates to Tanzanian coffee producers was developed, jointly integrating the narrative characteristics, styles, and expedients, as suggested in $[77,78,84]$. 
The narrative artifact was then designed to support educational activities that follow both PBL and CBL approaches.

In addition, an analytical description of a CE business model aimed at solving the problematic situation was introduced and described in detail using the sustainable circular business model innovation framework by Antikainen and Valkokari [72]. The solution provided is pivotal to the design of a complete CBL teaching activity. The description of the $C E$ business model indeed provided teachers and educators with the useful material for designing a guided inquiry to the problem solution. Table 2 reports the characteristics of the work outputs and their relationships with the aforementioned teaching approaches.

Table 2. A schematic representation of the research output.

\begin{tabular}{ccc}
\hline & $\begin{array}{c}\text { Case Study } \\
\text { Problematic Situation }\end{array}$ & Case Study Solution \\
\hline Tool & Narration & $\begin{array}{c}\text { Sustainable circular business model } \\
\text { innovation framework [76] }\end{array}$ \\
\hline Style & Narrative and descriptive & Descriptive and analytical \\
\hline $\begin{array}{c}\text { Supported teaching } \\
\text { approach }\end{array}$ & $\begin{array}{c}\text { Problem-based learning } \\
\text { Case-based learning }\end{array}$ & Case-based learning \\
\hline
\end{tabular}

\subsection{Data Sources}

The CE business model proposed in the case study was developed within an academic competition held in 2018 by a foundation belonging to one of the largest producers of roasted coffee in the world-the Giuseppe and Pericle Lavazza Foundation. One of the authors of this paper was a member of the proponent team while another supervised the work of the group. Useful and informative documentation enabled the illustration of the CE business model, designed in all its features, which was developed by the proponent team both before and after the competition.

Data relating to the problematic situation and the analytical description of the $\mathrm{CE}$ business model were drawn from various sources:

- Documentation provided for the project HowtUyoga which comprised:

- Private documentation (emails, drafts, internal communications) relating to the project, produced during the competition participation phase;

- Documentation relating to the project presented during the competition;

- Information contained on the website and dedicated to the Project (www.howtuyoga.com, accessed on 1 September 2021);

- Reviews of the literature concerning the methods of cultivating and processing coffee;

- Official documentation produced by the Tanzanian institutions relating to the agricultural sector and the local coffee production;

- Sector analysis conducted by international organizations, ONGs, and consulting companies.

In 2019, the proponent team traveled to Tanzania, in the Arusha region, in order to carry out an initial exploratory analysis of the actual possibility that the designed CE business model could be adopted. On that occasion, structured interviews were carried out with a few local coffee producers. The results of the interviews constituted an additional source of data for this work and made it possible to evaluate the main barriers to the adoption of the CE paradigm in the Tanzanian context.

\subsection{Data Analysis}

Data collected on the problematic situation were packaged in an organic narrative describing the problem and its context (real problem case) [38]. During the drafting of the narrative of the problematic situation, in line with [77], contradictions, dilemmas, and critical issues were highlighted. The narration was set up to follow the structure proposed 
in [37]: introduction to the problem, the context of the problem, problem questions. In line with the principles of the PBL, no fictionalized elements were added. In addition, bibliographic references are provided throughout the narration.

The collected data related the HowtUyoga's CE business model were coded using the sustainable circular business model innovation framework of Antikainen and Valkokari [72] as an ontological framework. We essentially chose that framework for its ability to integrate sustainability aspects with those of business and business ecosystems, which is useful to show a holistic approach to sustainability issues. Figure 1 depicts the framework, which involves 13 building blocks referring to 13 different ontological categories belonging to three different conceptual levels (business ecosystem, business, and sustainability impacts).

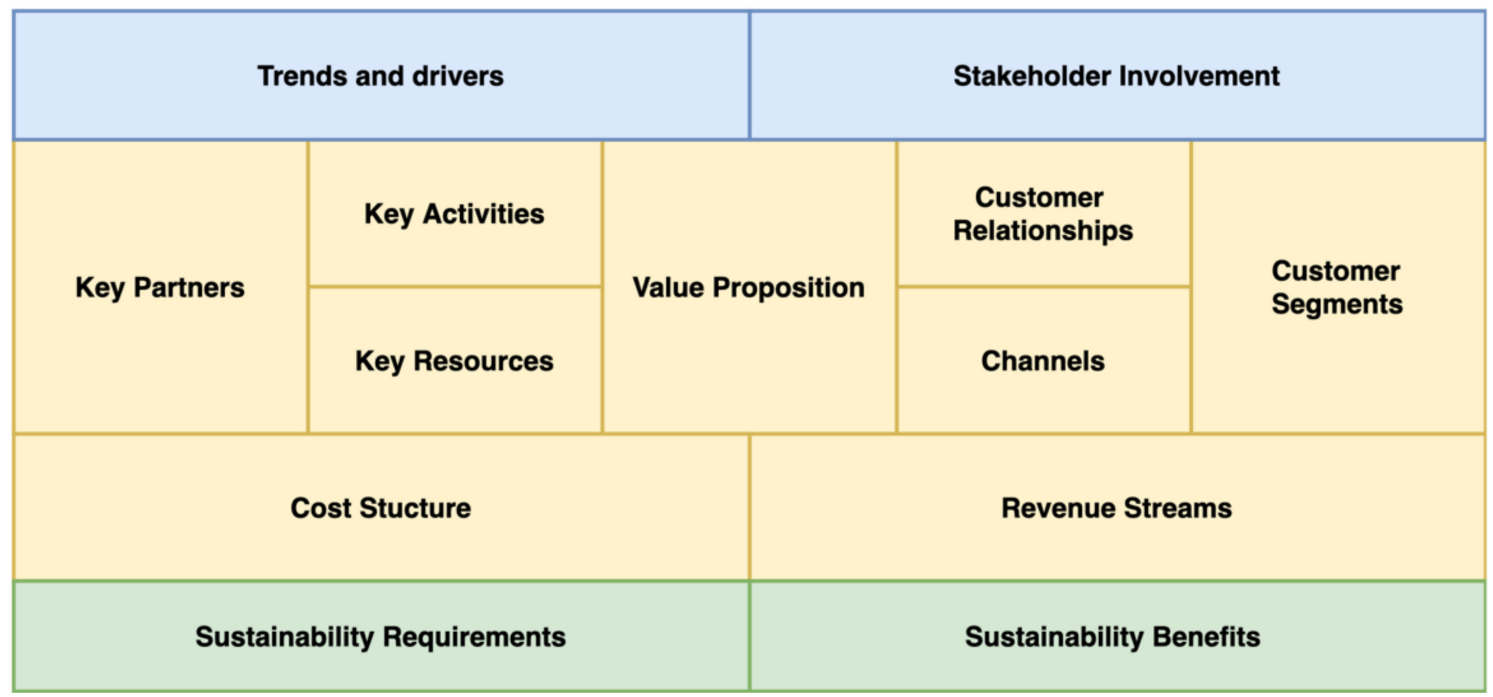

Figure 1. The sustainability circular business model innovation framework, graphics adapted from [72]: the business ecosystem is in blue, the business level (Osterwalder's business model canvas [69]) is in yellow, and the sustainability impacts level is in green.

Data were coded using the ontological categories described through a thematic qualitative analysis [85]. The themes, which univocally correspond to the ontological categories identified in the framework, were a priori defined (deductive thematic analysis). This activity was highly facilitated by the fact that, during the development phase of the project, the proposing group had presented the material using ontological categories similar to those described in the sustainable circular business model innovation framework. A discussion with the HowtUyoga proponent team was performed to validate the map.

\section{Problematic Situation}

In this section, we describe the problematic situation. To do so, we first briefly introduce the issues to be addressed (Section 4.1). Then, in Section 4.2, we describe the context of the problem: the main coffee cultivation techniques and by-products' treatments in addition to the current by-product's techniques of valorization are all introduced. Additionally, we provide a short description of Tanzanian coffee producers' organization. Finally, in Section 4.3 , we define the problem question.

\subsection{Introduction to the Problem}

Coffee is the most exported agricultural product from Tanzania: the sector employs 400,000 Tanzanians, organized in small organizations, mainly family businesses. The Tanzanian coffee farms therefore individually produce small amounts of coffee, which will then be auctioned to exporters through private trader or cooperative unions [86]. The cultivation of coffee is often combined with that of bananas, but the incomes of the producers remain too dependent on the price of coffee, and this, combined with low yields 
and antiquated agronomic techniques, makes it difficult for producers to grow in the medium to long term. In addition, as producers often live in isolated areas, their access to agricultural and entrepreneurial education is scarce and unstructured.

From an environmental point of view, Tanzanian coffee production could suffer significant impacts in terms of pollution due to the mismanagement of by-products and deforestation [86,87]. The cultivation and early processing of the coffee fruits indeed generate large amounts of organic by-products, containing high percentages of potentially dangerous substances such as caffeine [88]. At best, such by-products become input for the production of compost [89]. Climate change, on the other hand, is going to have negative impacts on coffee production, further eroding the yield of coffee fields [90].

The adoption of innovative CE business models could allow Tanzanian coffee farmers to sustainably exploit the resources at their disposal, access new forms of income, and then achieve economic, environmental, and social sustainability.

\subsection{Context of the Problem}

In this section, a brief and non-exhaustive introduction to coffee cultivation and its by-products is provided (Sections 4.2 .1 and 4.2.2) alongside a short introduction to the Tanzanian coffee production organizations (Section 4.2.3).

\subsubsection{Cultivation, Post-Harvesting Processes, and By-Products of Coffee}

Coffee cultivation plays a crucial role in the environmental and social future of the planet. This statement, far from being rhetorical and extravagant, is based on the fact that the cultivation of coffee is vital for the economy of many nations, as it is globally one of the most exported commodities by developing countries [91]. Coffee is the best-selling social drink in the world and it is estimated that nearly two and a half billion cups of coffee are consumed every day [92].

The coffee plant belongs to the Rubiaceae family, a very large botanical family: more than 80 of these belong to the Coffea sub-genus [93]. Coffeas are perennials and evergreens in nature: the two main qualities grown for commercial purposes, Arabica and Robusta, differ in the fact that the former is self-fertilized (it can reproduce by self-fertilization) whereas the latter is allogamous. The seeds produced as a result of pollination have the shape of small eggs, called coffee drupes (or cherries): a schematic anatomy is illustrated in Figure 2 [94]. Much of the fruit is discarded during coffee industry processes, since only the green part (bean) is utilized. The cultivation of coffee takes place in tropical regions mainly located between the Tropics of Cancer and Capricorn, wherein temperatures remain high for most of the year, frosts are absent or rare, and rains are abundant [95].

Coffee plants begin to bear fruit from the fifth year of life and have an average life span of 80 years. Fruit production decreases as the plant ages. The harvest is carried out at different times of the year, depending on the climatic conditions and the geographical area. Harvesting can be done by hand, selecting only the ripe reddish fruits (coffee cherries), or with semi-automated methods which, however, require a subsequent sorting of the crop.

After harvesting, the fruit is sent to the subsequent treatment phases that will allow the final product to be obtained. The Coffea fruit can undergo two main different processes: the dry method and the wet method. The two differ in terms of activities, times, generated by-products, and obtained outputs.

The wet method allows an output called washed coffee to be obtained, which is higher in quality than unwashed coffee, which is the dry method's output [96]. The process related to the wet method is schematized in Figure 3. 


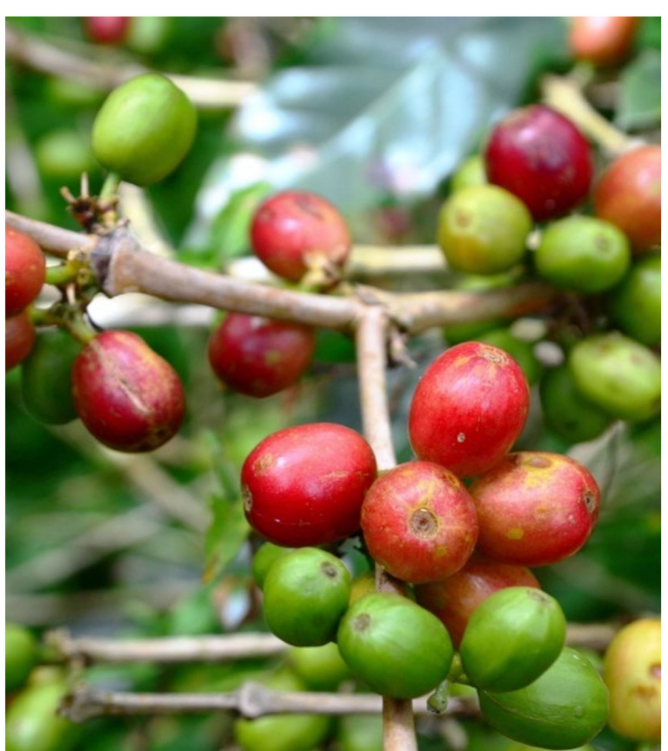

(a)

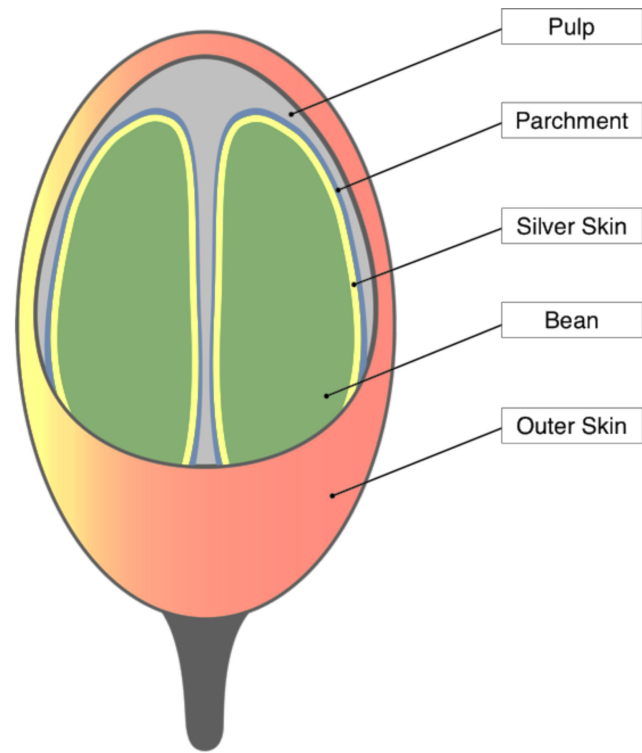

(b)

Figure 2. (a) Coffea plant laden with fruit (source: online royalty-free database pxfuel.com); (b) authors' anatomic schematization of a Coffea fruit adapted from [94]. The section shows the inside of the fruit containing the bean surrounded by the pulp.
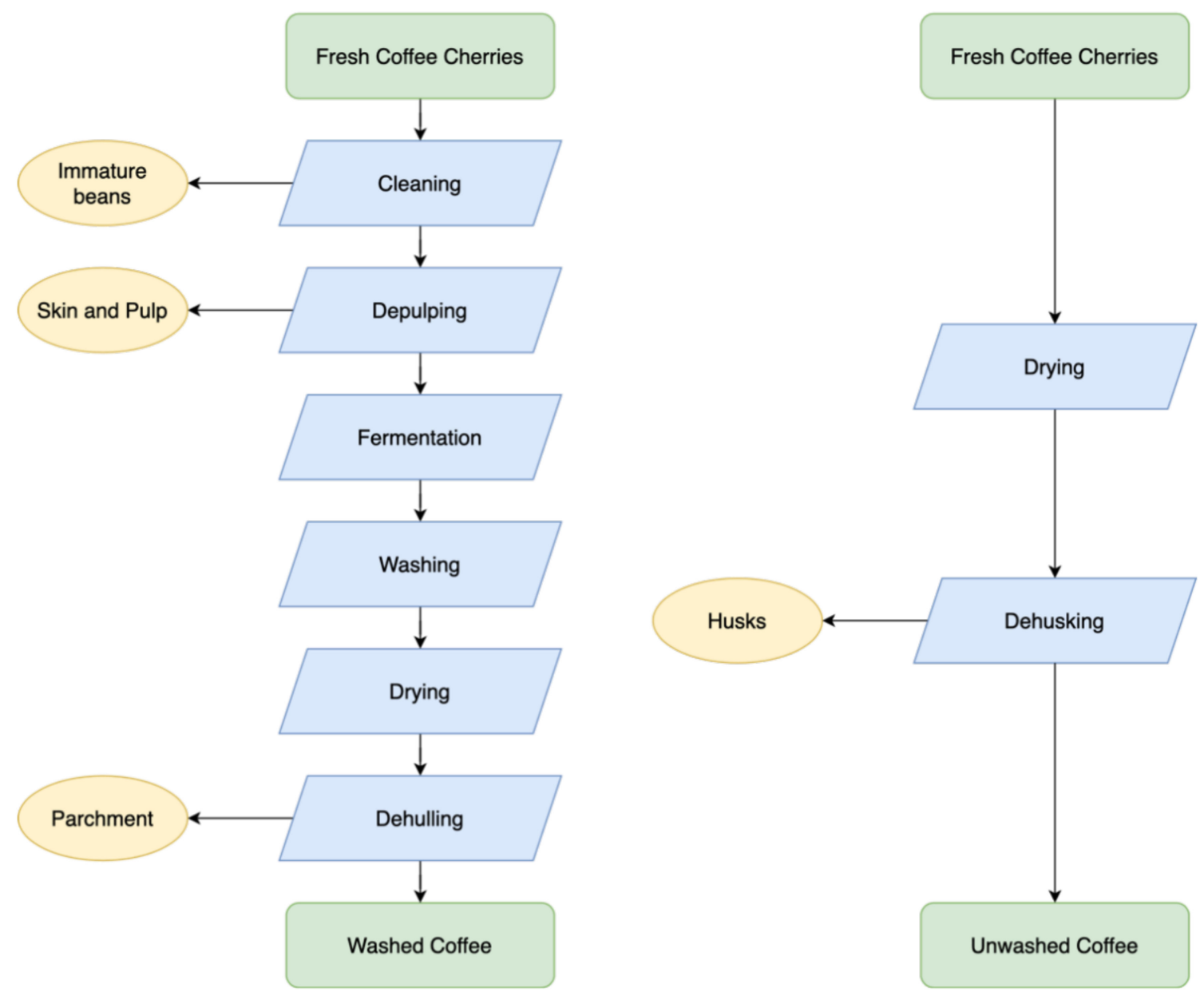

Figure 3. Main processing methods of coffee cherries (adapted from [94,96]). The main processes' by-products are highlighted in yellow. 
The wet method requires the cherries being depulped while still fresh. After depulping, the coffee beans are disposed to ferment for 2-3 days in order to eliminate the mucilage, a sticky substance that resists to depulping. The beans are then washed and left to dry. After drying, the parchment is mechanically eliminated (dehulling).

In the dry method, the cherries are dried in advance. After drying, the external parts of the dried coffee cherries (coffee husks) are mechanically removed (dehusking). The term "husks" identifies a dry mixture of skin, pulp, and parchment [96].

The wet method is associated with a more abundant water consumption whereas the dry method is preferred in places where humidity remains low and rains are infrequent [94]. Washed and un-washed coffee are then sent to subsequent roasting phases, which are not usually performed by the coffee farms themselves.

Spent coffee grounds are the only by-product of which consumers have a concrete perception: for every ton of green coffee (washed or unwashed), $550 \mathrm{~kg}$ of exhausted coffee is produced [97]. However, the cultivation and the processes that lead the coffee drupes to become soluble coffee generates a vast series of by-products: Figure 3 provides an overview of the main by-products. With reference to the wet method, the first by-product by generated weight is the pulp of the coffee cherry: between 450 and $500 \mathrm{~kg}$ of pulp is generated per ton of coffee collected [94,96]. Coffee pulp is a complex and heterogeneous organic material, rich in carbohydrates, proteins, and minerals, but also in substances such as polyphenols, tannins, and caffeine [98]. Coffee husks resulting from the dry method do not have a very different composition from that of the pulp, but are less rich in polyphenols and less hydrated [94].

For the output of the wet method to be qualitatively acceptable, only ripe and healthy coffee cherries should be processed. To this end, the fruits are sorted so as to exclude unripe or damaged drupes, which occur at higher percentages (15-20\% of the crop in India [99]), especially if the harvest is performed with methods other than handpicking. Ripe and damaged drupes appear to have a significantly different chemical composition from the healthy ones: lower levels of humidity, lower chemical concentrations of oils and proteins, and higher levels of caffeine [100].

In addition to the aforementioned by-products, it is necessary to specify that the wet method results in the use of significant quantities of water for the drupes washing: it is estimated that the process generates a total of 40-45 L of wastewater per kilogram of coffee [101].

\subsubsection{Valorization Techniques of Coffee By-Products}

Given the quantity of by-products produced by the coffee industry, there have been many and very different attempts to valorize these substances, which have had mixed results $[94,96]$. Those that are presented below are some of the most effective and efficient uses in terms of maximizing the economic value of these materials and preventing environmental pollution, based on $[94,96,102]$. Although all the by-products identified in the previous section can be considered organic waste easily assimilated by the environment, conferring large quantities of these substances risks poisoning the ecosystem in which the transfer takes place [101]. For most of the by-products of coffee processing, the high caffeine, phenol, and tannin contents, which are toxic to many living organisms, makes their disposal particularly delicate. Particularly harmful at an environmental level is the pulp which, both in quantity and quality, is the primary source of the environmental impact of the process on the environment [96].

The production of compost and vermicompost is useful for the valorization of husks and pulp. Such by-products should be integrated with other components, such as animal manure and fertilizers, to form effective compost even in the cultivation of the Coffea itself [103]. Coffee pulp can be integrated into livestock feeding [104]: however, an examination of the chemical composition of the feed is needed in order to preserve animals health as well as prevent poisoning or altered behaviors due to high caffeine levels [100]. 
By resorting to the fermentation of coffee husks and pulp, it is possible to produce ethanol with yields similar to those which can be obtained from the fermentation of other substrates such as corn stalks or barley straw [105]. By applying fermentation processes to coffee pulp, husks resulting from the dry method, and wastewater, it is also possible to obtain biogas [102]. Recent studies have shown the possibility of using pulp and husks to produce enzymes such as caffeinase, tannase, and pectinase: they have been involved in industrial processes such as the degradation of caffeine, the production of soluble beverages, and the extraction of fruit juices [94]. Starting from a wide range of by-products of the coffee cultivation and subsequent processes (husks, pulp, parchment, coffee leaves, chopped coffee wood), substrates for the production of edible mushrooms can be produced $[94,96]$. The cultivation of different mushroom species has been attempted with satisfactory results $[94,96,106,107]$.

\subsubsection{Coffee Cultivation in Tanzania}

Introduced from neighboring Ethiopia in the sixteenth century, the cultivation of coffee boasts a centuries-old tradition in Tanzania. It is configured as a subsistence crop run by family businesses or by small groups of farmers: for this reason, the government has made considerable efforts to increase the yield of the plantations, in order to increase the national domestic product-10\% of which depends on this crop [108] and to improve producers' living conditions. In [87], an overview of the average characteristics of coffee producing organizations is provided. A Tanzanian coffee farm has on average five workers within it, often linked to each other by family relationships, and covers an average of 1.5 hectares, of which almost one is employed for the cultivation of coffee. The cultivated plants have an average age of 32 years, and are therefore relatively old, which almost always results in suboptimal productions.

At a technical level, coffee-producing organizations in Tanzania are particularly illequipped: yields are very low due to the age of the plants, the absence of irrigation and monitoring tools, the scarce use of pesticides and fertilizers, and the poor knowledge of agronomic science by the members of the organization. Most organizations use the wet method, whereas the dry method is widespread in the northernmost regions and mostly for the fruits of Coffea robusta. Coffee processing always takes place within the organization and is followed by the sale of green coffee. Most of the operations required to process the coffee are manually performed [109]. Furthermore, coffee producers often live in conditions of poverty, essentially due to low incomes, in areas far away from inhabited centers. Malnutrition is a felt problem and the fact that most crops, such as coffee, are destined for export, jeopardizes the country's food security [110].

\subsection{Problem Question}

The described problematic situation is complex and many of the factors highlighted thus far need to be taken into consideration. To sum up and using the triple bottom line [71] as a categorical framework, we can fit the instances listed thus far into three categories:

- Economic - low yield of coffee cultivation, little or no crop diversification, price volatility;

- Social-poor entrepreneurial and agronomic education, poor local nutrition, social isolation of coffee farmers;

- Environmental-environmental risks associated with the mismanagement of coffee by-products, climate changes affecting coffee production, deforestation.

Based on the case of the average Tanzanian coffee farm, a CE business model capable of tackling the challenges falling into the three sustainability domains is now discussed in all of its components, using the sustainable circular business model innovation framework [72] as a guiding ontological framework. 


\section{HowtUyoga: A Circular Business Model}

In this section, a CE business model aimed at the solution of the problematic situation drafted in Section 4 is introduced and mapped (Section 5.1). All the components identified through the mapping are then described in-depth in Sections 5.2-5.8.

\subsection{Introduction to HowtUyoga}

The proposed CE business model was generated in 2018 by a heterogeneous group of students (two students in mechanical engineering, one student in computer engineering, one student in management engineering, one medical student with knowledge in mushroom cultivation) supervised by a university professor in business and management engineering. The circular solution was designed within a national academic competition organized by the Giuseppe and Pericle Lavazza Foundation, of which it resulted as the winning idea. The project was named one of the best sustainable ideas of the year by the Sustainable Development Solution Network [111].

The project, called HowtUyoga (in Swahili "Uyoga" means mushroom), aims to integrate a CE business model into coffee-producing organizations. The proposed CE business model aims to enhance some by-products of the cultivation and processing of coffee through the production of edible mushrooms. This solution goes alongside the traditional business model that sees organizations engaged in the cultivation and processing of coffee.

Figure 4 represents the proposed model using the sustainable circular business model innovation framework - the various components relating to it will be discussed in the following sections. Two distinct value propositions are identified. On the one hand, the first aims to meet the local community's need for nutritionally complete foods, by introducing fresh mushrooms to the market, produced using coffee by-products already available within the organization. On the other hand, the second aims to provide the coffee supply chain with products grown and processed within more environmentally and socially sustainable organizations. The two strands are identified in Figure 4 by different colors.

\subsection{Value Proposition}

In Tanzania, coffee is grown in remote areas which are often difficult to reach, within poor communities that do not always have access to nutritionally complete foods, especially in terms of proteins and oligonutrients. In these areas, the collection of wild mushrooms is practiced, especially by women. Wild mushrooms are often used for the preparation of some local dishes. However, a low and poor knowledge of mushroom species and the volatile availability of wild mushrooms does not allow this activity to be continuative. Mushrooms are already present in the Tanzanian market, although they are limited and not always available. In the proposed CE business model, the organization aims to offer fresh (or possibly preserved by drying) mushrooms of some selected species to the local community. The team conducted a survey on potentially cultivable species, taking into account three main parameters: (i) the compatibility of the species with the substrates from coffee production by-products; (ii) the nutritional properties of the species; and (iii) the demand for this species in the Tanzanian market. Following this analysis, the team selected three species on which coffee producing organizations could concentrate: the characteristics relating to the three species are indicated in Table 3. 


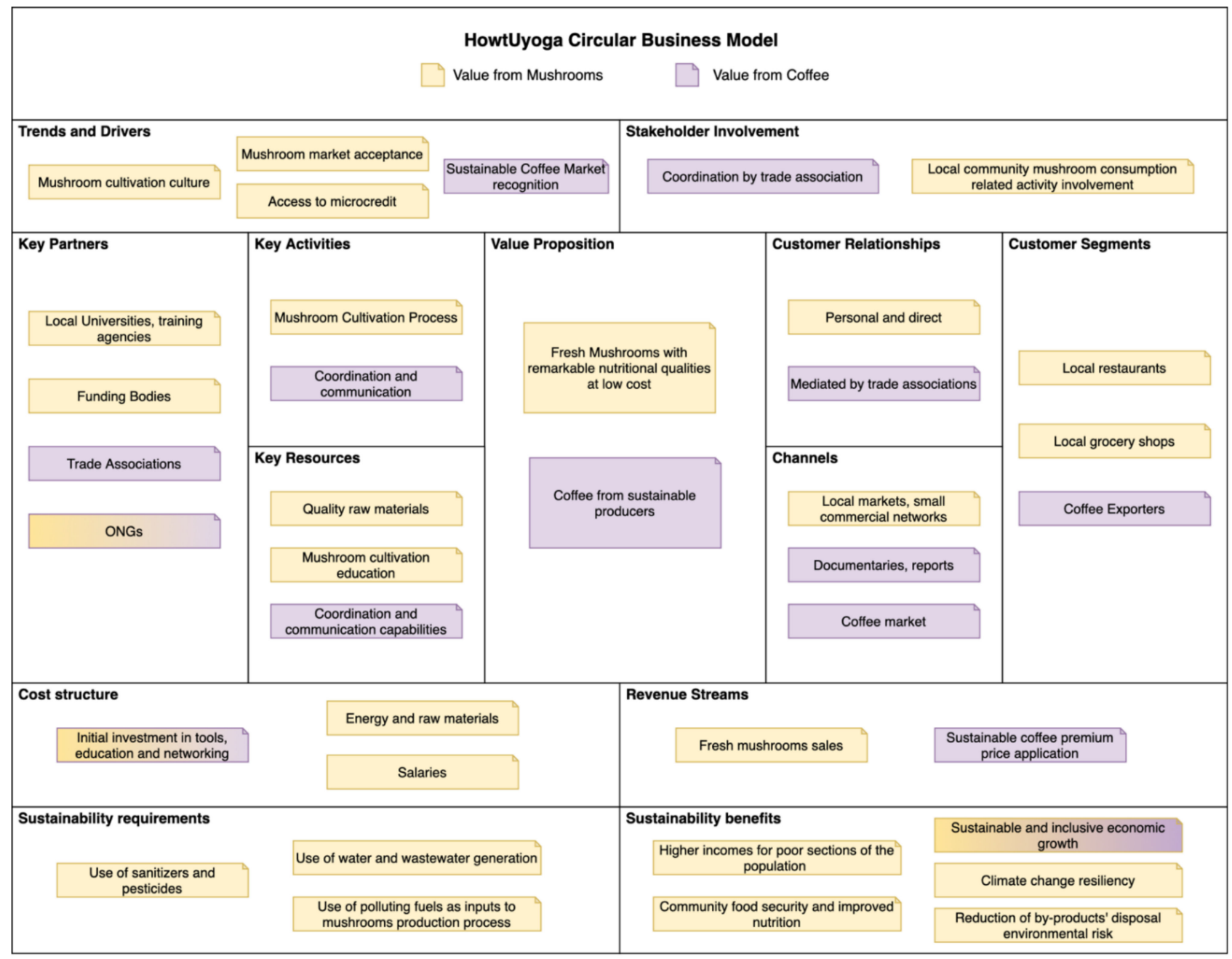

Figure 4. The sustainable circular business model innovation framework of the HowtUyoga's circular business model.

Table 3. Key features of the edible mushroom species selected by HowtUyoga (collected data refer to [112] and [88]).

\begin{tabular}{cccc}
\hline Species & $\begin{array}{c}\text { Proposed Coffee } \\
\text { By-Product }\end{array}$ & $\begin{array}{c}\text { Main Nutritional } \\
\text { Aspects }\end{array}$ & Tanzanian Market \\
\hline $\begin{array}{c}\text { Pleurotus } \\
\text { ostreatus }\end{array}$ & $\begin{array}{c}\text { Wood, leaves, husks, } \\
\text { parchment, pulp }\end{array}$ & $\begin{array}{c}\text { Rich in lovastatin, } \\
\text { vitamins of group B, } \\
\text { folate and vitamin D }\end{array}$ & $\begin{array}{c}\text { Demand is increasing from } \\
\text { 2006 and currently } \\
\text { exceeds supply }\end{array}$ \\
\hline $\begin{array}{c}\text { Lentinus } \\
\text { edodes }\end{array}$ & Pulp, husks & $\begin{array}{c}\text { Its active substance is } \\
\text { Lentinanus, which } \\
\text { has anti-viral, } \\
\text { anti-bacterial, and } \\
\text { antitumor properties }\end{array}$ & $\begin{array}{c}\text { Some variants are } \\
\text { indigenous and some } \\
\text { experimental cultures were } \\
\text { launched; demand is } \\
\text { increasing but still uncertain; }\end{array}$ \\
\hline $\begin{array}{c}\text { Agaricus } \\
\text { bisporus }\end{array}$ & Pulp & $\begin{array}{c}\text { Rich in proteins, iron, } \\
\text { potassium and } \\
\text { vitamin D }\end{array}$ & $\begin{array}{c}\text { Demand is increasing and } \\
\text { the species is widespread in } \\
\text { the market }\end{array}$ \\
\hline
\end{tabular}


The production of mushrooms starting with coffee by-product is an activity capable of significantly increasing the social and environmental sustainability of coffee-producing organizations, as will be explicated in Section 5.6. Coffee importers are increasingly sensitive to the sustainability of the entire supply chain, as demonstrated by different surveys $[113,114]$. Enhancing the internal sustainability of the organization therefore constitutes an effective strategy to deliver greater value to the entire supply chain as well as respond to the needs of Western markets which recognize socially and environmentally sustainable products. In this sense, therefore, the value proposition is two-fold: on the one hand, mushrooms from sustainable production with remarkable nutritional qualities are delivered to the local market; on the other hand, coffee supply chains are provided with products whose by-products are managed in a socially and environmentally sustainable way.

\subsection{Customer Segments, Customer Relationships, and Channels}

The first value proposition was addressed to the local community market. Fruits and vegetables are mainly sold to local markets and small shops [115,116]. Mushroom pickers and current small mushroom producers resell their products locally and numerous testimonies have recorded the economic sustainability of these activities $[115,116]$. Should the demand be fluctuating, the produced mushrooms could be easily preserved by drying, therefore accommodating fluctuations. Local restaurants are also interested in directly buying from producers. The consumption of mushrooms intended as a drug-food is also widespread: due to the remarkable nutritional properties, a diet rich in mushrooms is often prescribed for subjects suffering from viral diseases (e.g., AIDS) and diabetes [115-117]. Given the addressed customer segments, the organization will preferably aim for personal relationships with customers, relying as much as possible on small commercial networks if compatible with market conditions. The testimony reported in [116] from prof. Kivaisi is highly significant in this sense: she reported the experience of a Tanzanian mushroom producer dedicated to the resale of her products in her village of origin. The producer exploited her network of local acquaintances by directly reselling the fresh product to the end customer.

The sale of coffee from socially and environmentally sustainable organizations identifies coffee exporters as customers. In this sense, the organization of several producers into consortia or trade associations becomes necessary in order to increase the bargaining power of producers and ensure a considerable supply volume. The privileged tool available to producers to guarantee the recognition of their efforts in terms of sustainability are standardized certifications, the establishment of which, however, requires considerable effort in terms of coordination-horizontally among producers as well as vertically along the supply chain. The production of documentaries and reports raising awareness of sustainability initiatives is a key asset for the value of sustainable coffee to be recognized.

\subsection{Key Activities, Key Resources, and Key Partners}

The production of mushrooms starting from coffee by-products is a relatively simple activity: it requires a low initial investment, a few tools, and little manual labor [116]. It consists of five phases: the preparation of the substrate, packaging, growth, harvesting, disposal. The HowtUyoga project refers to a mushroom production process derived from $[88,116]$.

The selected by-products must first be collected, and if necessary, chopped (as in the case of wood residues) and/or left to ferment (as in the case of pulp). Following these preliminary operations, the organic material thus obtained is mixed with other substances depending on the chosen mushroom species (e.g., chicken manure for Agaricus bisporus). The mixture is then bagged and heated to eliminate pathogens. The heating treatment can be rudimentally carried out by steaming the bags with water. The mycelium of the selected mushroom species is then inoculated. The inoculated bags are placed in a dark, fresh, and clean environment for a period of time that depends on the species and environmental 
variables. When the mycelium has completely filled the mixture inside each bag, cuts are made, the environment is lit, and the carpophores start to develop. Carpophores are the part of the fungus that we usually call mushroom and they are technically the reproductive organ of the fungus itself. In this phase, it is important to frequently hydrate the bags, and since the carpophores continuously ripen, it is necessary to collect the ripe ones to prevent degradation.

The described process is linear and easy to manage, so much so that it is already in use in many Tanzanian mushroom farms with scarce access to mushroom cultivation knowledge [116]. Despite this, it should be noted that the correct execution of some activities is crucial for obtaining the final product. Key activities are:

- The correct composition and pasteurization of the substrate;

- The inoculation of quality mycelia;

- The proper disinfection of the environment where the mycelia develops and the harvesting processes take place.

In order to ensure the proper execution of these activities, having a good education in mushroom growing as well as finding quality raw materials is crucial. Education in mushroom growing is a fundamental prerequisite, as this ensures good knowledge of the processes, tools, and raw materials involved, allowing one to avoid problems such as resources inefficiency and waste mismanagement [116]. For this reason, it becomes essential to identify strategic partners, such as local universities or local training institutions, to properly train the organizations involved. The Tanzanian government has indeed already made many efforts to promote mushroom cultivation using training courses addressed to young people and women. These initiatives were driven by the low initial investment and the high potential related to mushroom cultivation. Credit institutions could constitute an additional strategic partner for microfinance [116,117].

The marketing activities propedeutic to the sale of the final product could be crucial for the purposes of the proposed CE business model. However, the Tanzanian mushroom market is in conditions of scarce supply, making these activities a non-essential asset.

The coordination and communication activities with other producers and other actors within the supply chain are crucial for the recognition of the higher social and environmental sustainability of the produced coffee. Partnerships aimed at coordination and mediation could be pursued with the NGOs present in the Tanzanian territory.

\subsection{Cost Structure and Revenue Streams}

The sale of fresh mushrooms is currently an economically sustainable activity in Tanzania capable of improving the economic situation of the producers' households. Kajumulo Kivaisi [116] reported the case of a small mushroom producer capable of earning TSH 251,100 in profits from a single production cycle of $75 \mathrm{~kg}$ (the average annual income in rural Tanzania is approximately TSH 150,000 [118]). The possibility of being recognized as a premium coffee price due to a more sustainable cultivation and by-products management would be an additional source of revenue.

The costs of mushroom production are essentially determined by those of mycelia, of the consumable material used (bags, fuel for pasteurization, sanitizers), and of salaries. However, the activities related to the small-scale production of mushrooms can be easily integrated with other agricultural activities, requiring neither constant commitment over time nor highly specialized personnel. The initial investment for an organization starting from scratch was estimated in [116] and amounts to approximately TSH 400,000 for a yield of $75 \mathrm{~kg}$ of mushrooms per cycle. Based on this estimate, the payback time would be equal to 2.3 production cycles. By reducing the costs related to the purchase and transport of the raw materials, the use of coffee by-products to produce the substrate would make the activity even more cost effective. As discussed in (e.g., [88,94]), in other geographical contexts (e.g., Mexico), such a hypothesis has been confirmed. The real implementation of the proposed CE business model would also help validate the hypothesis in relation to the Tanzanian case. 


\subsection{Sustainability Benefits}

The adoption of the CE business model proposed by HowtUyoga is potentially able to increase the socio-economic and environmental sustainability of the adopting organizations.

The higher revenues generated that increase the economic resilience of coffee-producing organizations and lead to higher incomes are often correlated with better chances to access to education and healthcare, especially in developing countries [116]. The diversification of the business portfolio makes organizations more resilient from an economic, financial and environmental point of view, preventing them from solely depending on coffee cultivation and on the fluctuations of its market [119]. Coffee is an essentially export commodity: the Tanzanian internal demand accounts for only $7 \%$ of the total internal supply [120]. The cultivation of mushrooms for self-consumption and sale in local markets is able to ensure enhanced food security for residents. The introduction of the identified mushroom species in the local diet also helps fight malnutrition in a broad sense, allowing members of the organization and their communities to have access to micronutrients and trace elements that would otherwise be difficult to obtain.

The use of the by-products of coffee processing as a resource prevents their uncontrolled introduction in the environment, neutralizing a possible source of pollution. Moreover, the cultivation of mushrooms is itself an environmentally sustainable activity, indicated in many plans for sustainable agricultural development as an activity to be encouraged because of its little soil consumption.

The adoption of the proposed CE business model may generate impacts in terms of gender equality: indeed, much of the knowledge relating to mushrooms (e.g., species, marketing, uses) is currently owned by the female Tanzanian population and the wild mushrooms' collection is more practiced by women [121].

The Sustainable Development Goals (SDGs) framework (developed by the United Nations within the 2030 Agenda [122]) was adopted to frame all the instances highlighted thus far. Table 4 illustrates the potentially impacted SDGs.

\subsection{Sustainability Requirements}

The environmental costs related to the adoption of the proposed CE business model are essentially attributable to the use of pesticides and sanitizers. The preparation of the substrate requires a high level of hygiene in order to prevent infestations of pathogens such as molds or competing fungi. The environments suitable for the development of the mycelium and carpophores can be easily infested with insects (e.g., flies) capable of compromising production due to the particular thermo-hygrometric conditions. It is then necessary to guarantee high levels of hygiene in these environments. If correctly managed, the required level of hygiene does not have high impacts in terms of pollution [116].

Mushroom cultivation is not prohibitive in terms of water consumption itself, but in environments characterized by drought, it may be necessary to arrange tools and processes aimed at limiting water consumption (e.g., recovering the water deployed in the substrate pasteurization phase).

Finally, it is necessary to point out that particular attention should be paid to the energy source to be used to pasteurize the substrate. Currently, the few mushroom growers present in rural Tanzania rely on the combustion of biomass (wood and agricultural waste). If such a use is controlled and sustainably managed, the environmental impacts would be very low. 
Table 4. Characterization of the societal benefits related to the adoption of the CE business model proposed by HowtUyoga according to the United Nations' SDGs.

\begin{tabular}{|c|c|c|}
\hline SDG & $\begin{array}{l}\text { HowtUyoga CE } \\
\text { Business Model's } \\
\text { Expected Action }\end{array}$ & $\begin{array}{c}\text { Potentially Impacted } \\
\text { Global } \\
\text { Agenda Indicator }\end{array}$ \\
\hline $\begin{array}{l}1 \text { End poverty in all its } \\
\text { forms everywhere }\end{array}$ & $\begin{array}{c}\text { Increase in the income of coffee } \\
\text { farmers by } \\
\text { introducing fungiculture }\end{array}$ & $\begin{array}{l}\text { 1.1.1 Proportion of population } \\
\text { below the international poverty } \\
\text { line, by sex, age, employment } \\
\text { status and geographical } \\
\text { location (urban/rural) } \\
2.3 .2 \text { Average income of } \\
\text { small-scale food producers, by } \\
\text { sex and indigenous status }{ }^{1}\end{array}$ \\
\hline $\begin{array}{l}2 \text { End hunger, achieve } \\
\text { food security and } \\
\text { improved nutrition and } \\
\text { promote sustainable } \\
\text { agriculture }\end{array}$ & $\begin{array}{l}\text { Improve the local diet by } \\
\text { introducing specific mushroom } \\
\text { species with excellent } \\
\text { nutritional properties }\end{array}$ & $\begin{array}{c}\text { 2.1.1 Prevalence of } \\
\text { undernourishment } \\
\text { 2.4.1 Proportion of agricultural } \\
\text { area under productive and } \\
\text { sustainable agriculture }\end{array}$ \\
\hline $\begin{array}{l}3 \text { Ensure healthy lives and } \\
\text { promote well-being for all } \\
\text { at all ages }\end{array}$ & $\begin{array}{l}\text { Improve the local diet } \\
\text { particularly for pregnant } \\
\text { women and children, by } \\
\text { encouraging mushroom } \\
\text { consumption }\end{array}$ & $\begin{array}{l}\text { 3.1.1 Maternal morality ratio } \\
\text { 3.2.1 Under-5 mortality rate }\end{array}$ \\
\hline $\begin{array}{l}8 \text { Promote sustained, } \\
\text { inclusive and sustainable } \\
\text { economic growth, full and } \\
\text { productive employment } \\
\text { and decent work for all }\end{array}$ & $\begin{array}{l}\text { Create decent jobs in mushroom } \\
\text { cultivation sector and diversify } \\
\text { the Tanzanian coffee } \\
\text { producers' activities }\end{array}$ & $\begin{array}{l}\text { 8.5.2 Unemployment rate, by } \\
\text { sex, age and persons } \\
\text { with disabilities } \\
\text { 2.3.2 Average income of } \\
\text { small-scale food producers, by } \\
\text { sex and indigenous status }{ }^{1}\end{array}$ \\
\hline $\begin{array}{l}12 \text { Ensure sustainable } \\
\text { consumption and } \\
\text { production patterns }\end{array}$ & $\begin{array}{l}\text { Encourage use of agricultural } \\
\text { by-products as a substrate for } \\
\text { mushroom cultivation }\end{array}$ & $\begin{array}{l}\text { 12.2.2 Domestic material } \\
\text { consumption, domestic material } \\
\text { consumption per capita, and } \\
\text { domestic material consumption } \\
\text { per GDP }\end{array}$ \\
\hline $\begin{array}{l}13 \text { Take urgent action to } \\
\text { combat climate change } \\
\text { and its impacts }\end{array}$ & $\begin{array}{l}\text { Make Tanzanian agriculture } \\
\text { more resilient to climate change } \\
\text { by introducing fungiculture }\end{array}$ & $\begin{array}{l}\text { 13.1.1.b Number of least } \\
\text { developed countries and } \\
\text { small-island developing states } \\
\text { that are receiving specialized } \\
\text { support and amounts of } \\
\text { support, including finance, } \\
\text { technology, and } \\
\text { capacity-building, for } \\
\text { mechanisms for raising } \\
\text { capacities for effective climate } \\
\text { change-related planning and } \\
\text { management, including } \\
\text { focusing on women, youth and } \\
\text { local and } \\
\text { marginalized communities }\end{array}$ \\
\hline
\end{tabular}

15 Protect, restore and promote sustainable use of terrestrial ecosystems, sustainably manage forests, combat desertification, and halt and reverse land degradation and halt biodiversity loss

Fight deforestation by introducing mushroom cultivation exploiting existing coffee by-products
Forest area as a proportion of total land area

${ }^{1}$ Originally linked to another SDG, considered in relation to a positive bi-directional interaction. 


\subsection{Trends, Drivers, and Stakeholder Involvement}

A relevant factor for the successful adoption of the proposed CE business model is increasing the demand for mushrooms by the local markets. However, the demand is currently growing for some species (e.g., Pleurotus ostreatus) but remains uncertain for others (e.g., Lentinula edodes). Initiatives aimed at encouraging the local community to consume mushrooms and to appreciate their nutritional and medical properties would be useful [122]. These marketing activities could take place, for example, by means of small social events and through informative material distribution.

In order to facilitate the implementation of the presented CE business model, the demand for sustainable coffee should hopefully grow. Fortunately, this trend is already underway, driven by the new sensitivity of consumers to the issues of environmental and social sustainability of goods imported from developing countries. As mentioned in Section 5.3, in order to boost this trend, the communication of the sustainability supply chain performances constitute a fundamental asset. In coordination with coffee retailers, producer organizations can contribute to the production of material to be integrated into advertising campaigns and/or sustainability reports.

\section{Use of the Case: CBL and PBL Approaches}

In this study, the narrative of a problematic situation and the analytical presentation of a CE business model aimed at its resolution were proposed.

The obtained narrative highlights different aspects of the problem relating to the three dimensions of sustainability (economic, social, and environmental), and invites students to search for holistic business solutions capable of addressing all the sustainability dimensions. Some insights relating to current valorization techniques of coffee by-products are also given in order to provide students with a background about the current state of the art. In this sense, the problem narrative integrates the attributes (simple, informative, focused on learning items) listed by Silva et al. [84].

A schematic representation of the potential PBL and CBL activities is proposed below (Figure 5). However, the proposed narrative will need to be adapted by the faculty of the target audience, the resources available (e.g., time), and the educational objectives to be pursued.

When following a PBL approach, the class should not be preliminarily introduced to specific tools useful for addressing the problem questions. In this sense, few data on the problematic situation should be provided (e.g., the current coffee by-products valorization techniques are not described) and no tools aimed at CE business models mapping should be preliminarily provided. A possible problem question to be asked to the class is the following: "Based on the case of the average Tanzanian coffee farm, it is required to develop a circular business model capable of tackling the challenges falling into the three sustainability domains. It is required to describe the business model in all its elements and the relationships among them". Participants are divided into groups and have a more or less lengthy period (according to [84], no more than $16 \mathrm{~h}$ ) to define, map, and describe a CE business model capable of solving the identified problematic situation. Students are invited to search for knowledge using external resources.

The students' output is mapped using a tool freely chosen by the participants (different groups could use different tools). The solutions produced by the students are then presented and discussed in class. The discussion can be stimulated by designing this phase as a challenge between groups of students, alternately called to "criticize" the peers' work. Participants should have the opportunity to discuss their solutions and compare them with those provided by others. This phase can be managed through different approaches (e.g., the submission of a written report or a presentation) that will then influence the assessment strategy. In order to design a teaching activity which is as devoted to the interaction between students as possible, both in the solution generation phase and in the presentation of the output, techniques and strategies to foster communication among participants can be adopted. In this sense, team solution generation, open group discussion, 
and peer assessment could represent the best design options $[123,124]$. These choices would be mainly aimed at maximizing the enhancement of students' soft skills. The positive relation between the adoption of a PBL approach and soft skills enhancement is already known [125] and becomes precious, especially in a post-pandemic teaching context affected by a general lack of real communication and networking opportunities.

\section{Problem based learning approach}

\section{Case based learning approach}
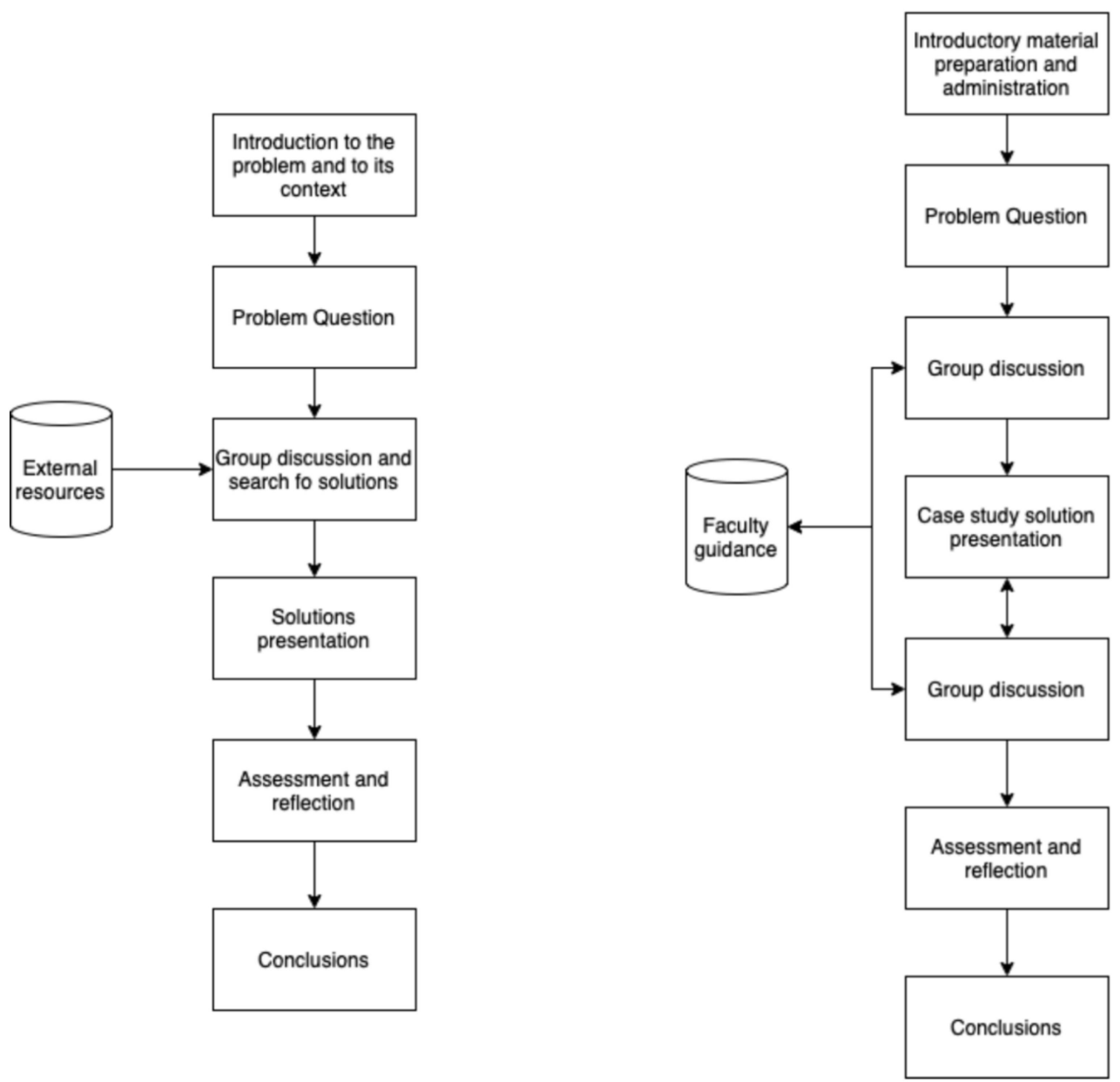

Figure 5. How to use the case: problem-based learning and case-based learning approaches.

Following a PBL approach dramatically stimulates self-directed learning [81], pushing students to find information, tools, and solutions without adopting any facultychosen strategy. Given this, it requires students' high involvement and high independent learning skills.

The CBL teaching activity design should be rather oriented to the guided inquiry of the CE business model proposed by HowtUyoga. After an initial introduction to the problem, students should be led to the HowtUyoga solution through the use of probing questions such as "How could mushroom cultivation be implemented in coffee producing organizations?", "Which areas of sustainability do you think they would be most impacted by the introduction of this activity?", "Who could be key partners for the correct implementation of this business model?". During the guided inquiry, the students are maieutically driven to the ontological representation of the HowtUyoga solution through the use of a framework (such as the one adopted in this paper) chosen by the faculty. This approach requires more commitment by the faculty, that, while moderating the discussion, must 
actively engage in the transfer of knowledge and skills related to CE business models mapping the use of tools. Furthermore, the faculty should also correct students' mistakes during the activities. Once the guided inquiry is finished, an assessment and reflection phase follows. Such a phase can be carried out by subjecting the participants to tests aimed at evaluating the knowledge and skills learned.

The teaching activity designs presented can be followed by using both a traditional approach as well as a flipped classroom approach. In particular, the flipped classroom approach and PBL integration were the subject of numerous studies that showed its effectiveness in terms of student engagement and problem-solving ability [126], critical thinking, and scientific literacy [127].

\section{Research and Practical Implications}

In this study, a teaching case study that may potentially be integrated into university courses or training courses on CE addressed to professionals and practitioners was proposed. The case can be used for problem-based and case-based learning teaching activities that, as mentioned, are extremely useful for the transfer of CE-related skills and knowledge [38].

In addition, this study expands the existing literature on CE business models in the agri-food field, with a focus on mushroom production from coffee by-products in the context of developing countries. The literature on mushroom cultivation using coffee byproducts is indeed extensive and well established, as regards the processes and mushroom species available as well as the technical aspects related to cultivation $[88,96,106,115]$ : however, to the knowledge of the authors, no study has investigated the implementation of this activity at the business model level. The research by Kivaisi [116] can be considered seminal, since it pioneered the exploration of the case of Tanzanian rural mushroom producers. However, even in [116], there was a lack of considerations regarding the sustainability of the case study presented, and the adopted BM was not explicated.

From a practical point of view, the HowtUyoga case represents an innovative CE business model proposal to be integrated within coffee-producing organizations. The interest towards sustainable coffee supply chains on the part of coffee importers, transnational organizations, and governments is increasing, as is the sensitivity of consumers. The mapping of the CE business models helps to clarify the impacts in terms of the sustainability of the proposed model. This study also provides an example of analytical representation and description of a CE business model. The use of the sustainable circular business model innovation framework made it possible to show how to break down the HowtUyoga CE business model in order to narrate it, making it understandable and more easily communicable. This operation is crucial in the design and definition phase of innovative CE business models: the study presented here constitutes an example, for use by managers and startuppers, which is useful for understanding the use of ontological frameworks as tools for presenting new business ideas or the description of existing business ideas.

\section{Conclusions}

This study has proposed the narrative of a problematic situation and the description of a CE business model useful for the design of teaching activities that adopt PBL and CBL approaches. The use of such approaches has proven to be valid and efficient in the area of sustainability and CE. Furthermore, the study provided an in-depth analytical description of an agri-food CE business model, thus practically useful to managers, startuppers, and practitioners as an example of CE business models framework-driven analysis. Additionally, the paper expanded the existing literature on $\mathrm{CE}$ business models by presenting a case study from the context of developing nations.

Parallel to the formulation of the problem, a precise and analytical mapping of the HowtUyoga's CE business model was provided. The mapping took place using the sustainable circular business model framework [72] that proved extremely useful to frame all aspects relating to the investigated CE business model. The use, given the versatility 
and simplicity that distinguish it, could also be suggested for educational purposes within CBL activities. Indications on how to use the proposed CE business model in class were also proposed, with two teaching activity designs' proposals adopting PBL and CBL. The problematic situation presented herein will need to be administered to assess its effectiveness in terms of student engagement, informativeness, and clarity. From this point of view, the resources, times, and the educational context play a fundamental role for the correct development of the teaching activity.

This study has some limitations. First, HowtUyoga is in a conceptual development phase: a first exploratory survey conducted in the field allowed us to partially evaluate its feasibility, but to date the model has not been implemented. As a consequence, the discussed results need to be further validated. Conversely, the CE business model was mainly proposed for educational purposes, demonstrating how to use a framework to map and describe a CE business solution. Second, the problem statement forces students to find a feasible CE solution, assuming $\mathrm{CE}$ as a resolutive paradigm. According to [128] this approach could determine an over-commitment to $\mathrm{CE}$, potentially resulting in a dogmatic and uncritical attitude towards the paradigm.

Future research will focus on the assessment of the effectiveness of teaching case studies in terms of CE skills and knowledge transfer. In particular, additional research related to this teaching case study will focus on the controlled administration of the teaching activity to students, in order to evaluate their involvement and their knowledge and skills acquisition.

The case study supports both PBL and CBL teaching approaches; however, in the management area, no study appeared to be aimed at comparing the two approaches in terms of effectiveness. In this sense, future research could be aimed at cross-checking the two approaches, perhaps using teaching case studies structured such as the one developed herein. On the other hand, with reference to the analyzed CE business model, future research could focus on the empirical investigation of the sustainability performance relative to mushroom growers operating in developing countries.

Author Contributions: Conceptualization, all authors; methodology, all authors; validation, all authors; formal analysis, F.P.L.; resources, F.P.L.; data curation, F.P.L.; writing-original draft preparation, all authors; writing - review and editing, all authors; visualization, F.P.L.; supervision, B.S. and P.P. All authors have read and agreed to the published version of the manuscript.

Funding: This research received no external funding.

Institutional Review Board Statement: Not applicable.

Informed Consent Statement: Not applicable.

Acknowledgments: The authors thank the members of the HowtUyoga team (Ivano Bilenchi, Francesco Forina, Francesco Paolo Lagrasta, Luca Latini, and Lorenzo Parrulli) for the permission to write about their project and the provision of data related to it.

Conflicts of Interest: The authors declare no conflict of interest.

\section{References}

1. Brammer, S.; Branicki, L.; Linnenluecke, M.; Smith, T. Grand challenges in management research: Attributes, achievements, and advancement. Aus. J. Man. 2019, 44,517-533. [CrossRef]

2. Ritchie, H.; Roser, M. Environmental Impacts of Food Production-Our World in Data. Available online: https: / / ourworldindata. org/environmental-impacts-of-food (accessed on 21 July 2021).

3. Poore, J.; Nemecek, T. Reducing food's environmental impacts through producers and consumers. Science 2018, 360, 987-992. [CrossRef] [PubMed]

4. Barrett, C.B. Smallholder market participation: Concepts and evidence from eastern and southern Africa. Food Policy 2008, 33, 299-317. [CrossRef]

5. Gómez, M.I.; Meemken, E.; Verteramo Chiu, L.J. Agricultural Value Chains and Social and Environmental Impacts: Trends, Challenges, and Policy Options; FAO: Rome, Italy, 2020; pp. 3-4. [CrossRef]

6. Rasmussen, L.V.; Coolsaet, B.; Martin, A.; Mertz, O.; Pascual, U.; Corbera, E.; Dawson, N.; Fisher, J.A.; Franks, P.; Ryan, C.M. Social-ecological outcomes of agricultural intensification. Nat. Sustain. 2018, 1, 275-282. [CrossRef] 
7. FAO. Food Loss and Waste Database. Available online: http://www.fao.org/platform-food-loss-waste/flw-data/en/ (accessed on 21 July 2021).

8. Turon, X.; Venus, J.; Arshadi, M.; Koutinas, M.; Lin, C.S.K.; Koutinas, A. Food Waste and Byproduct Valorization through Bio-processing: Opportunities and Challenges. Bio. Res. 2014, 9, 5774-5777. [CrossRef]

9. Zhu, Z.; Gavahian, M.; Barba, F.J.; Rossellò-Soto, E.; Bursać Kovačević, D.; Putnik, P.; Denoy, G. Valorization of waste and by-products from food industries through the use of innovative technologies. In Agri-Food Industry Strategies for Healthy Diets and Sustainability; Barba, F.J., Putnik, P., Kovačević, D.B., Eds.; Elsevier: Amsterdam, The Netherlands, 2020; pp. 249-266. [CrossRef]

10. Nattassha, R.; Handayati, Y.; Simatupang, T.M.; Siallagan, M. Understanding circular economy implementation in the agri-food supply chain: The case of an Indonesian organic fertiliser producer. Agric. Food Sec. 2020, 9, 1-16. [CrossRef]

11. Korhonen, J.; Honkasalo, A.; Seppälä, J. Circular Economy: The Concept and its Limitations. Ecol. Econ. 2018, 143, 37-46. [CrossRef]

12. Naustdalslid, J. Circular economy in China-The environmental dimension of the harmonious society. Int. J. Sustain. Dev. 2014, 21, 303-313. [CrossRef]

13. Ellen McArthur Foundation. Towards the Circular Economy Vol. 1: An Economic and Business Rationale for an Accelerated Transition. Available online: https:/ / emf.thirdlight.com/link/x8ay372a3r11-k6775n/@/preview/1?o (accessed on 21 July 2021).

14. Laubinger, F.; Lanzi, E.; Chateau, J. Labour Market Consequences of a Transition to a Circular Economy: A Review Paper. IRERE 2020, 14, 381-416. [CrossRef]

15. Aguilar-Hernandez, G.A.; Dias Rodrigues, J.F.; Tukker, A. Macroeconomic, social and environmental impacts of a circular economy up to 2050: A meta-analysis of prospective studies. J. Clean. Prod. 2021, 278, 381-416. [CrossRef]

16. Gutberlet, J.; Carenzo, S.; Kain, J.H.; Mantovani Martiniano de Azevedo, A. Waste Picker Organizations and Their Contribution to the Circular Economy: Two Case Studies from a Global South Perspective. Resources 2017, 6, 52. [CrossRef]

17. Padilla-Rivera, A.; Do Carmo, B.B.T.; Arcese, G.; Merveille, N. Social circular economy indicators: Selection through fuzzy delphi method. Sustain. Prod. Consum. 2021, 26, 101-110. [CrossRef]

18. Esposito, B.; Sessa, M.R.; Sica, D.; Malandrino, O. Towards Circular Economy in the Agri-Food Sector. A Systematic Literature Review. Sustainability 2020, 12, 7401. [CrossRef]

19. Joint Research Centre (European Commission). Future Transitions for the Bioeconomy towards Sustainable Development and a ClimateNeutral Economy: Knowledge Synthesis: Final Report; Publications Office of the European Union: Luxembourg, 2020. [CrossRef]

20. COM. A New Circular Economy Action Plan. 2020. Available online: https://eur-lex.europa.eu/legal-content/EN/TXT/?qid= 1583933814386\&uri=COM:2020:98:FIN (accessed on 1 September 2021).

21. Abad-Segura, E.; de la Fuente, A.B.; González-Zamar, M.D.; Belmonte-Ureña, L.J. Effects of Circular Economy Policies on the Environment and Sustainable Growth: Worldwide Research. Sustainability 2020, 12, 5792. [CrossRef]

22. Evans, S.; Vladimirova, D.; Holgado, M.; van Fossen, K.; Yang, M.; Silva, E.A.; Barlow, C.Y. Business Model Innovation for Sustainability: Towards a Unified Perspective for Creation of Sustainable Business Models. Bus. Strat. Environ. 2017, 26, 597-608. [CrossRef]

23. Fraccascia, L.; Giannoccaro, I.; Agarwal, A.; Hansen, E.G. Business models for the circular economy: Opportunities and challenges. Bus. Strat. Environ. 2019, 28, 430-432. [CrossRef]

24. Panwar, R.; Niesten, E. Advancing Circular Economy. Bus. Strat. Environ. 2020, 29, 2890-2892. [CrossRef]

25. Bocken, N.M.P.; Ritala, P.; Huotari, P. The Circular Economy: Exploring the Introduction of the Concept Among S\&P 500 Firms. J. Ind. Ecol. 2017, 21, 487-490. [CrossRef]

26. Gedam, V.V.; Raut, R.D.; Lopes de Sousa Jabbour, A.B.; Tanksale, A.N.; Narkhede, B.E. Circular economy practices in a developing economy: Barriers to be defeated. J. Clean. Prod. 2021, 311, 127670. [CrossRef]

27. Mishra, J.L.; Chiwenga, K.D.; Ali, K. Collaboration as an enabler for circular economy: A case study of a developing country. Manag. Decis. 2019, 59, 1784-1800. [CrossRef]

28. Jabbour, C.J.C.; de Sousa Jabbour, A.B.L.; Sarkis, J.; Filho, M.G. Unlocking the circular economy through new business models based on large-scale data: An integrative framework and research agenda. Technol. Forecast. Soc. Chang. 2019, 144, 546-552. [CrossRef]

29. Ngan, S.L.; How, B.S.; Teng, S.Y.; Promentilla, M.A.B.; Yatim, P.; Er, A.C.; Lam, H.L. Prioritization of sustainability indicators for promoting the circular economy: The case of developing countries. Renew. Sustain. Energy Rev. 2019, 111, 314-331. [CrossRef]

30. Solaimani, S.; Bouwman, H. A framework for the alignment of business model and business processes: A generic model for trans-sector innovation. Bus. Process Man. J. 2012, 18, 655-679. [CrossRef]

31. Bernon, M.; Tjahjono, B.; Ripanti, E.F. Aligning retail reverse logistics practice with circular economy values: An exploratory framework. Prod. Plan. Cont. 2018, 29, 483-497. [CrossRef]

32. Ellen McArthur Foundation. the Circular Economy in Detail. Available online: https://archive.ellenmacarthurfoundation.org/ explore/the-circular-economy-in-detail (accessed on 3 August 2021).

33. De Mattos, C.A.; De Albuquerque, T.L.M. Enabling Factors and Strategies for the Transition Toward a Circular Economy (CE). Sustainability 2018, 12, 4628. [CrossRef]

34. Couckuyt, D.; Van Looy, A. Green BPM as a Business-Oriented Discipline: A Systematic Mapping Study and Research Agenda. Sustainability 2019, 11, 4200. [CrossRef] 
35. Kopnina, H. Green-washing or best case practices? Using circular economy and Cradle to Cradle case studies in business education. J. Clean. Prod. 2019, 219, 613-621. [CrossRef]

36. Atkinson, R.K.; Derry, S.J.; Renkl, A.; Wortham, D. Learning from Examples: Instructional Principles from the Worked Examples Research. Rev. Educ. Res. 2000, 70, 181-214. [CrossRef]

37. Van den Bossche, P.; Segers, M.; Gijbels, D.; Dochy, F. Effects of Problem-Based Learning in Business Education: A Comparison Between a PBL and a Conventional Educational Approach. In Educational Innovation in Economics and Business: Pedagogy, Technology and Innovation; Ottewill, R., Borredon, L., Falque, L., Macfarlane, B., Wall, A., Eds.; Springer: Dordrecht, The Netherlands, 2004; pp. 205-227. [CrossRef]

38. Kirchherr, J.; Piscicelli, L. Towards an Education for the Circular Economy (ECE): Five Teaching Principles and a Case Study. Resour. Conserv. Recycl. 2019, 150, 104406. [CrossRef]

39. Van Keulen, M.; Kirchherr, J. The implementation of the Circular Economy: Barriers and enablers in the coffee value chain. J. Clean. Prod. 2021, 281, 125033. [CrossRef]

40. Geissdoerfer, M.; Pieroni, M.P.P.; Pigosso, D.C.A.; Soufani, K. Circular business models: A review. J. Clean. Prod. 2020, 277, 123741. [CrossRef]

41. Kirchherr, J.; Reike, D.; Hekkert, M. Conceptualizing the circular economy: An analysis of 114 definitions. Resour. Conserv. Recycl. 2017, 127, 221-232. [CrossRef]

42. Geissdoerfer, M.; Savaget, P.; Bocken, N.M.P.; Hultink, E.J. The Circular Economy-A new sustainability paradigm? J. Clean. Prod. 2017, 143, 757-768. [CrossRef]

43. Ghisellini, P.; Cialani, C.; Ulgiati, S. A review on circular economy: The expected transition to a balanced interplay of environmental and economic systems. J. Clean. Prod. 2016, 114, 11-32. [CrossRef]

44. Lieder, M.; Rashid, A. Towards circular economy implementation: A comprehensive review in context of manufacturing industry. J. Clean. Prod. 2016, 115, 36-51. [CrossRef]

45. Blomsma, F.; Brennan, G. The Emergence of Circular Economy: A New Framing Around Prolonging Resource Productivity. J. Ind. Ecol. 2017, 21, 603-614. [CrossRef]

46. Sauvé, S.; Bernard, S.; Sloan, P. Environmental sciences, sustainable development and circular economy: Alternative concepts for trans-disciplinary research. Environ. Dev. 2016, 17, 48-56. [CrossRef]

47. Murray, A.; Skene, K.; Haynes, K. The Circular Economy: An Interdisciplinary Exploration of the Concept and Application in a Global Context. J. Bus. Ethics 2017, 40, 369-380. [CrossRef]

48. Lewandowski, M. Designing the Business Models for Circular Economy-Towards the Conceptual Framework. Sustainability 2016, 8, 43. [CrossRef]

49. Frenken, K. Sustainability perspectives on the sharing economy. Environ. Innov. Soc. Transit. 2017, 23, 1-2. [CrossRef]

50. Koumparou, D. Circular economy and social sustainability. In Proceedings of the Solid Waste Management \& its Contribution to Circular Economy, Athens, Greece, 14-15 December 2017; pp. 4-15.

51. Walker, A.M.; Opferkuch, K.; Roos Lindgreen, E.; Simboli, A.; Vermeulen, W.J.V.; Raggi, A. Assessing the social sustainability of circular economy practices: Industry perspectives from Italy and the Netherlands. Sustain. Prod. Consum. 2021, 27, 831-844. [CrossRef]

52. Geissdoerfer, M.; Savaget, P.; Evans, S. The Cambridge Business Model Innovation Process. Proc. Manufact. 2017, 8, 262-269. [CrossRef]

53. Teece, D.J. Business Models, Business Strategy and Innovation. Long Range Plan. 2010, 43, 172-194. [CrossRef]

54. Zott, C.; Amit, R.; Massa, L. The Business Model: Recent Developments and Future Research. J. Man. 2011, 37, 1019-1042. [CrossRef]

55. Jensen, A.B. Do we need one business model definition? J. Bus. Models 2013, 1, 61-84. [CrossRef]

56. Nußholz, J.L.K. Circular Business Models: Defining a Concept and Framing an Emerging Research Field. Sustainability 2017, 9 , 1810. [CrossRef]

57. Schwager, P.; Moser, F. The Application of Chemical Leasing Business Models in Mexico. Environ. Sci. Poll. Res. Int. 2006, 13, 131-137. [CrossRef]

58. Oghazi, P.; Mostaghel, R. Circular Business Model Challenges and Lessons Learned-An Industrial Perspective. Sustainability 2018, 10, 739. [CrossRef]

59. Zucchella, A.; Previtali, P. Circular business models for sustainable development: A "waste is food" restorative ecosystem. Bus. Strat. Environ. 2019, 28, 274-285. [CrossRef]

60. Lahti, T.; Wincent, J.; Parida, V. A Definition and Theoretical Review of the Circular Economy, Value Creation, and Sustainable Business Models: Where Are We Now and Where Should Research Move in the Future? Sustainability 2018, 10, 2799. [CrossRef]

61. Ünal, E.; Urbinati, A.; Chiaroni, D.; Manzini, R. Value Creation in Circular Business Models: The case of a US small medium enterprise in the building sector. Resour. Conserv. Recycl. 2019, 146, 291-307. [CrossRef]

62. Bocken, N.M.P.; de Pauw, I.; Bakker, C.; Van Der Grinten, B. Product design and business model strategies for a circular economy. J. Ind. Prod. Eng. 2016, 33, 308-320. [CrossRef]

63. Lüdeke-Freund, F.; Gold, S.; Bocken, N.M.P. A Review and Typology of Circular Economy Business Model Patterns. J. Ind. Ecol. 2019, 23, 36-61. [CrossRef]

64. Zott, C.; Amit, R. Business Model Design and the Performance of Entrepreneurial Firms. Organ. Sci. 2007, 18, 181-199. [CrossRef] 
65. Osterwalder, A.; Pigneur, Y.; Tucci, C.L. Clarifying Business Models: Origins, Present, and Future of the Concept. Commun. Assoc. Inf. Syst. 2005, 16, 1. [CrossRef]

66. Lima, M.; Baudier, P. Business Model Canvas Acceptance among French Entrepreneursh ip Students: Principles for Enhancing Innovation Artefacts in Business Education. J. Inn. Econ. Man. 2017, 23, 159-183. [CrossRef]

67. Blank, S. Why the Lean Start-Up Changes Everything Harvard Business Review. Available online: https://hbr.org/2013/05/ why-the-lean-start-up-changes-everything (accessed on 1 September 2021).

68. Osterwalder, A. The Business Model Ontology a Proposition in a Design Science Approach. Ph.D. Thesis, University of Lausanne, Lausanne, Switzerland, 2004.

69. Osterwalder, A.; Pigneur, Y. Business Model Generation: A Handbook for Visionaries, Game Changers, and Challengers, 1st ed.; John Wiley \& Sons: Hoboken, NJ, USA, 2010.

70. Dewulf, K. A Game-based tool for Sustainable Product and Business Model Innovation in the Fuzzy Front End. In Proceedings of the Knowledge Collaboration \& Learning for Sustainable Innovation ERSCP-EMSU Conference, Delft, The Netherlands, 25-29 October 2010; TU Delft: Delft, The Netherlands, 2010. Available online: https:/ / core.ac.uk/download/pdf/55871546.pdf (accessed on 1 September 2021).

71. Elkington, J. Accounting for the Triple Bottom Line. Meas. Bus. Excell. 1998, 2, 18-22. [CrossRef]

72. Antikainen, M.; Valkokari, K. A Framework for Sustainable Circular Business Model Innovation. TIM Rev. 2016, 6, 5-12. [CrossRef]

73. Daou, A.; Mallat, C.; Chammas, G.; Cerantola, N.; Kayed, S.; Saliba, N.A. The Ecocanvas as a business model canvas for a circular economy. J. Clean. Prod. 2020, 258, 20938. [CrossRef]

74. Leonard-Barton, D. A Dual Methodology for Case Studies: Synergistic Use of a Longitudinal Single Site with Replicated Multiple Sites. Organ. Sci. 1990, 3, 248-266. [CrossRef]

75. Yin, R.K. Case Study Research: Design and Methods, 1st ed.; SAGE: Thousand Oaks, CA, USA, 2009.

76. Benbasat, I.; Goldenstein, D.; Mead, M. The Case Research Strategy in Studies of Information Systems. Man. Inf. Syst. Q. 1987, 11, 369. [CrossRef]

77. Sahay, A. Teaching Case: How to Write. Available online: https://www.researchgate.net/publication/323392698_Teaching_ Case_How_to_Write (accessed on 28 August 2021).

78. Mostert, M. Challenges of Case-Based Teaching. Behav. Anal. Today 2007, 8, 434-442. [CrossRef]

79. Gertzman, A.D.; Kolodner, J.L. A case study of problem-based learning in a middle school science classroom: Lessons learned. In Proceedings of the 1996 International Conference on Learning Sciences, Evanston, IL, USA, 25-27 July 1996; AACE: Evanston, IL, USA, 1996; pp. 91-98. [CrossRef]

80. Stinson, J.E.; Milter, R.G. Problem-based learning in business education: Curriculum design and implementation issues. New Dir. Teach. Learn. 1996, 68, 33-42. [CrossRef]

81. Srinivasan, M.; Wilkes, M.; Stevenson, F.; Nguyen, T.; Slavin, S. Comparing problem-based learning with case-based learning: Effects of a major curricular shift at two institutions. Acad. Med. 2007, 82, 74-82. [CrossRef]

82. Bocken, N.M.P.; Rana, P.; Short, S.W. Value mapping for sustainable business thinking. J. Ind. Prod. Eng. 2015, 32, 67-81. [CrossRef]

83. Malve-Ahlroth, S.; Suominen, J.; Piia, N. Problem-Based Project Learning Is Key to the Circular Economy. Available online: https:/ / talk.turkuamk.fi/kiertotalous / problem-based-project-learning-is-key-to-the-circular-economy/ (accessed on 1 September 2021).

84. Silva, A.B.D.; De Bispo, A.C.K.; Rodriguez, G.D.; Vasquez, F.I.F. Problem-based learning: A proposal for structuring PBL and its implications for learning among students in an undergraduate management degree program. Rev. Gest. 2018, 25, 160-177. [CrossRef]

85. Kiger, M.E.; Varpio, L. Thematic analysis of qualitative data: AMEE Guide. Med. Teach. 2020, 42, 846-854. [CrossRef]

86. Baffes, J. (World Bank) Tanzania's Coffee Sector: Constraints and Challenges in a Global Environment. Available online: https: / / openknowledge.worldbank.org/handle/10986/9695 (accessed on 21 August 2021).

87. COSA Sustainability Assessment. Coffee Production in Tanzania: 2009-2010. Available online: https://thecosa.org/wp-content/ uploads/2015/05/Tanzania-Coffee-2009-2010-Evaluation-COSA-2011-.pdf (accessed on 21 August 2021).

88. Martínez-Carrera, D.; Aguilar, A.; Martínez, W.; Bonilla, M.; Morales, P.; Sobal, M. Commercial Production and Marketing of Edible Mushrooms Cultivated on Coffee Pulp in Mexico. In Coffee Biotechnology and Quality; Soccol, C.R., Pandey, A., Roussos, S., Sera, T., Eds.; Springer: Dordrecht, The Netherlands, 2000. [CrossRef]

89. Reetsch, A.; Kimaro, D.; Feger, K.H.; Schwärzel, K. Traditional and Adapted Composting Practices Applied in Smallholder BananaCoffee-Based Farming Systems: Case Studies from Kagera and Morogoro Regions, Tanzania. In Organic Waste Composting through Nexus Thinking: Practices, Policies, and Trends; Hettiarachchi, H., Caucci, S., Schwärzel, K., Eds.; Springer: Cham, Switzerland, 2020. [CrossRef]

90. Craparo, A.C.W.; Van Asten, P.J.A.; Läderack, P.; Jassogne, L.T.P.; Grab, S.W. Coffea arabica yields decline in Tanzania due to climate change: Global implications. Agric. Forest Meteor. 2015, 207, 1-10. [CrossRef]

91. Pendergrast, M. Coffee Second Only to Oil? Available online: https://www.thefreelibrary.com/Coffee+second+only+to+oil\%3F+ Is+coffee+really+the+second+largest...-a0198849799 (accessed on 21 August 2021).

92. Neumann Gruppe. The World of Coffee in 2017. Available online: https://www.sintercafe.com/uploads/File/2012 / presentations/0.neumann.pdf (accessed on 21 August 2021). 
93. Clifford, M.N.; Williams, T.; Bridson, D. Chlorogenic acids and caffeine as possible taxonomic criteria in Coffea and Psilanthus. Phytochemistry 1989, 28, 829-838. [CrossRef]

94. Murthy, P.S.; Madhava Naidu, M. Sustainable management of coffee industry by-products and value addition-A review. Resour. Conserv. Recycl. 2012, 66, 45-58. [CrossRef]

95. Murthy, P.S.; Basavaraj, K.; Naidu, M. Journey of Indian Coffee Quality. J. Ind. Coffee 2001, 3, 18-21.

96. Alves, R.C.; Rodrigues, F.; Antónia Nunes, M.; Vinha, A.F.; Oliveira, M.B. State of the art in coffee processing by-products. In Handbook of Coffee Processing By-Products; Galanakis, C.M., Ed.; Academic Press: New York, NY, USA, 2017. [CrossRef]

97. Pfluger, R.A. Soluble coffee processing. In Solid Wastes: Origin, Collection, Processing and Disposal, 1st ed.; Mantell, C.L., Ed.; John Wiley and Sons: Hoboken, NJ, USA, 1975; pp. 365-376.

98. Franca, A.S.; Oliveira, L.S.; Mendonça, J.C.F.; Silva, X.A. Physical and chemical attributes of defective crude and roasted coffee beans. Food Chem. 2005, 90, 89-94. [CrossRef]

99. Ramalakshmi, K.; Kubra, I.R.; Rao, L.J.M. Physicochemical characteristics of green coffee: Comparison of graded and defective beans. J. Food Sci. 2007, 72, 333-337. [CrossRef]

100. Mazzafera, P. Chemical composition of defective coffee beans. Food Chem. 1999, 64, 547-554. [CrossRef]

101. Torres-Valenzuela, L.S.; Serna-Jiménez, J.A.; Martínez, K. Coffee By-Products: Nowadays and Perspectives. In Coffee-Production and Research; Toledo Castanheira, D., Ed.; IntechOpen: London, UK, 2020. [CrossRef]

102. Limousy, L.; Jeguirim, M.; Labaki, M. Energy applications of coffee processing by-products. In Handbook of Coffee Processing By-Products; Galanakis, C.M., Ed.; Academic Press: New York, NY, USA, 2017. [CrossRef]

103. Dzung, N.A.; Dzung, T.T.; Khanh, V.T.P. Evaluation of Coffee Husk Compost for Improving Soil Fertility and Sustainable Coffee Production in Rural Central Highland of Vietnam. Resour. Environ. 2013, 3, 77-82. [CrossRef]

104. Didanna, H.L. A Critical Review on Feed Value of Coffee Waste for Livestock Feeding Undefined. Available online: https:/ / www.semanticscholar.org/paper / A-critical-review-on-feed-value-of-coffee-waste-forDidanna/dd7359868b68e37118 b64d921184ad7cb4fb9617 (accessed on 18 August 2021).

105. Gouvea, B.M.; Torres, C.; Franca, A.S.; Oliveira, L.S.; Oliveira, E.S. Feasibility of ethanol production from coffee husks. Biotechnol. Lett. 2009, 31, 1315-1319. [CrossRef]

106. Leifa, F.; Soccol, C.R.; Pandey, A. Production of Mushrooms on Brazilian Coffee Industry Residues. In Coffee Biotechnology and Quality: Proceedings of the 3rd International Seminar on Biotechnology in the Coffee Agro-Industry; Sera, T., Soccol, C.R., Pandey, A., Roussos, S., Eds.; Springer: Dordrecht, The Netherlands, 2000. [CrossRef]

107. Leifa, F.; Pandey, A.; Soccol, C.R. Production of Flammulina velutipes on coffee husk and coffee spent-ground. Braz. Arch. Biol. Technol. 2001, 44, 205-212. [CrossRef]

108. Tanzania Coffee Board. Tanzania Coffee Industry. Available online: https://www.coffeeboard.or.tz/News_publications/ startegy_english.pdf (accessed on 21 August 2021).

109. USAID. Tanzania Coffee Industry Value Chain Analysis. Available online: https://pdf.usaid.gov/pdf_docs/PA00JXX7.pdf (accessed on 1 September 2021).

110. Tanzania Food and Nutrition Centre. Nutrition-Relevant Actions in Tanzania. Available online: https://www.unscn.org/layout/ modules/resources/files/Tanzania1993.pdf (accessed on 24 August 2021).

111. Sustainable Development Solutions Network—Youth. Youth Solutions Report 2018, 2nd ed.; SDSN-Youth: New York, NY, USA, 2018; p. 38. Available online: https://issuu.com/youthsolutionsreport/docs/youth_solutions_report_2018 (accessed on 24 August 2021).

112. Murthy, P.S.; Manonmani, H.K. Bioconversion of Coffee Industry Wastes with White Rot Fungus Pleurotus florida. Res. J. Environ. Sci. 2008, 2, 45-150. [CrossRef]

113. Piao, R.S.; Fonseca, L.; Januário, E.; Macchione Saes, M.S.; Florencio de Almeida, L. The adoption of Voluntary Sustainability Standards (VSS) and value chain upgrading in the Brazilian coffee production context. J. Rural Stud. 2019, 71, 13-22. [CrossRef]

114. Rich, K.M.; Chengappa, P.G.; Muniyappa, A.; Yadava, C.G.; Manjyapura, G.S.; Pradeepa Babu, B.N.; Shubha, Y.C.; Rich, M. Coffee certification in India: Awareness, practices, and sustainability perception of growers. Agroecol. Sustain. Food Sys. 2018, 42, 448-474. [CrossRef]

115. Mosha, P.J. Study of Oyster Mushroom and Markets in Tanania: Case Study of Hay District. Master's Thesis, Wageningen University, Wageningen, The Netherlands, 2011. Available online: https:/ / edepot.wur.nl/173507 (accessed on 24 August 2021).

116. Kivaisi, A.K. (University of Dar es Salaam), Mushroom Cultivation in Tanzania. Available online: https://www. sustainableagtanzania.com/_webedit/uploaded-files/All\%20Files/agronomy/Mushroom\%20Farming.pdf (accessed on 24 August 2021).

117. Jumanne, M. Mushroom Cultivation in Tanzania. Available online: https://medium.com/@mohamedbiologist/mushroomcultivation-in-tanzania-70ea9e272376 (accessed on 24 August 2021).

118. Aikaeli, J.; REPOA. Determinants of Rural Income in Tanzania: An Empirical Approach. Available online: https:/ /www.repoa.or. tz/wp-content/uploads/2020/07/rr10_4.pdf (accessed on 24 August 2021).

119. Solymosi, K.; Grit, T. Brewing up Climate Resilience in the Coffee Sector-Global Coffee Platform. 2018. Available online: https://www.sustaincoffee.org/assets/resources/Brewing_up_Climate_Resilience_in_the_Coffee_Sector.pdf (accessed on 24 August 2021). 
120. Ruben, R.; Allen, C.; Boureima, F.; Mhando, D.G.; Dijkxhoorn, Y. Coffee Value Chain Analysis in the Southern Highlands of Tanzania: Final Report. DG-DEVCO. Value Chain Analysis for Development Project (VCA4D CTR 2016/375-804). Available online: https://research.wur.nl/en/publications/coffee-value-chain-analysis-in-the-southern-highlands-of-tanzania (accessed on 24 August 2021).

121. Tibuhwa, D.D. Wild mushroom- an underutilized healthy food resource and income generator: Experience from Tanzania rural areas. J. Ethnobiol. Ethnomed. 2013, 9, 49. [CrossRef] [PubMed]

122. UN. Transforming Our World: The 2030 Agenda for Sustainable Development. Available online: https://sdgs.un.org/ publications/transforming-our-world-2030-agenda-sustainable-development-17981 (accessed on 24 August 2021).

123. Akindele, D.O. Enhancing Teamwork and Communication Skills Among First Year Students at the University of Botswana. TESOL J. 2012, 6, 2-15. Available online: https:/ / tesol-international-journal.com/wp-content/uploads/2013/11/V6_TESOL.pdf\#page=6 (accessed on 24 August 2021).

124. Ying, J. The Importance of the Discussion Method in the Undergraduate Business Classroom. Humanist. Man. J. 2020, 5, 251-278. [CrossRef]

125. Deep, S.; Salleh, B.M.; Othman, H. Study on problem-based learning towards improving soft skills of students in effective communication class. IJIL 2019, 25, 17-34. [CrossRef]

126. Chua, K.J.; Islam, M.R. The hybrid Project-Based Learning-Flipped Classroom: A design project module redesigned to foster learning and engagement. Int. J. Mech. Eng. Educ. 2020, 49, 289-315. [CrossRef]

127. Paristiowati, M.; Cahyana, U.; Bulan, B. Implementation of Problem-based Learning-Flipped Classroom Model in Chemistry and Its Effect on Scientific Literacy. Univ. J. Educ. Res. 2019, 7, 56-60. [CrossRef]

128. Kopnina, H. Teaching Circular Economy: Overcoming the Challenge of Green-washing. In Handbook of Engaged Sustainability; Marques, J., Ed.; Springer: Cham, Switzerland, 2018. 